\title{
A Review of Nervonic Acid Production in Plants: Prospects for the Genetic Engineering of High Nervonic Acid Cultivars Plants
}

\author{
Fang Liu' ${ }^{1}$, Pandi Wang ${ }^{1}$, Xiaojuan Xiong ${ }^{1}$, Xinhua Zeng ${ }^{1}$, Xiaobo Zhang ${ }^{2 *}$ and Gang Wu ${ }^{1 *}$ \\ ${ }^{1}$ Key Laboratory of Biology and Genetic Improvement of Oil Crops, Ministry of Agriculture and Rural Affairs, Oil Crops \\ Research Institute, Chinese Academy of Agricultural Sciences, Wuhan, China, ${ }^{2}$ Life Science and Technology Center, China \\ National Seed Group Co. Ltd., Wuhan, China
}

OPEN ACCESS

Edited by:

Hong Luo,

Clemson University, United States

Reviewed by:

Fu-Li Li,

Qingdao Institute of Bioenergy and Bioprocess Technology (CAS),

China

Noemi Ruiz-Lopez,

University of Malaga, Spain

*Correspondence:

Xiaobo Zhang

zhangxiaobo4@sinochem.com

Gang Wu

wugang@caas.cn

Specialty section:

This article was submitted to

Plant Biotechnology,

a section of the journal

Frontiers in Plant Science

Received: 30 November 2020

Accepted: 29 January 2021

Published: 05 March 2021

Citation:

Liu F, Wang $P$, Xiong $X$, Zeng $X$,

Zhang $X$ and WU G (2021) A Review of Nervonic Acid Production in Plants: Prospects for the Genetic Engineering of High Nervonic Acid Cultivars

Plants. Front. Plant Sci. 12:626625.

doi: 10.3389/fp/s.2021.626625
Nervonic acid (NA) is a very-long-chain monounsaturated fatty acid that plays crucial roles in brain development and has attracted widespread research interest. The markets encouraged the development of a refined, NA-enriched plant oil as feedstocks for the needed further studies of NA biological functions to the end commercial application. Plant seed oils offer a renewable and environmentally friendly source of NA, but their industrial production is presently hindered by various factors. This review focuses on the NA biosynthesis and assembly, NA resources from plants, and the genetic engineering of NA biosynthesis in oil crops, discusses the factors that affect NA production in genetically engineered oil crops, and provides prospects for the application of NA and prospective trends in the engineering of NA. This review emphasizes the progress made toward various NA-related topics and explores the limitations and trends, thereby providing integrated and comprehensive insight into the nature of NA production mechanisms during genetic engineering. Furthermore, this report supports further work involving the manipulation of NA production through transgenic technologies and molecular breeding for the enhancement of crop nutritional quality or creation of plant biochemical factories to produce NA for use in nutraceutical, pharmaceutical, and chemical industries.

Keywords: nervonic acid, production, plant source, 3-ketoacyl-CoA synthase, genetic engineering, oil crops

\section{HIGHLIGHTS}

This review presents various nervonic acid production related topics in plants, highlighting the factors that affect NA production in genetically engineered oil crops and provides prospects for the application of NA.

\section{INTRODUCTION}

Nervonic acid (NA; 24:1 $\Delta 15,24: 1 \quad \omega-9$; cis-tetracos-15-enoic acid) is a very-long-chain monounsaturated fatty acid (VLCMFA, 22-26 carbons) (Merrill et al., 1997; Figure 1) that was first isolated in shark brain and molecular structure was determined more than 100 years ago; it is also known as shark oil acid or selacholeic Acid (Tsujimoto and Kimura, 1926). It was found that the shark brain could repair itself in a short time after being severely damaged, suggesting the 


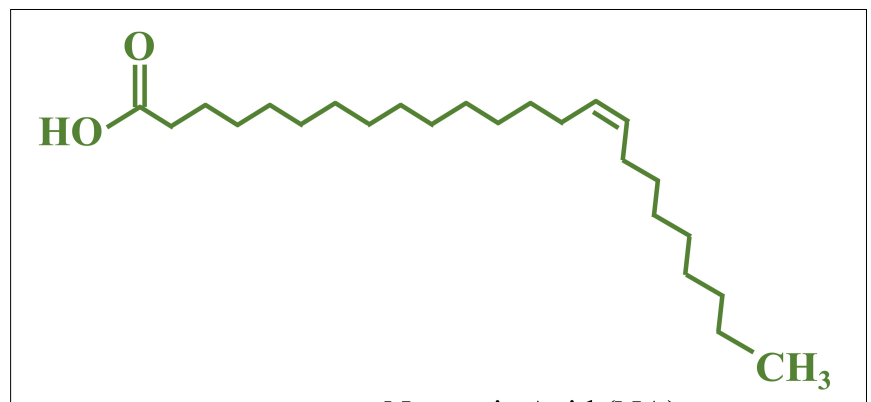

Nervonic Acid (NA);

24:1 $\Delta 15$;

24:1 $\omega-9$;

Name: $\quad$ Cis-15-tetracosenic acid;

Shark oil acid;

Selacholeic Acid

Molecular formula: $\mathrm{C}_{24} \mathrm{H}_{46} \mathrm{O}_{2}$

Molecular weight:

366.6

Classification:

$\omega-9$ very-long-chain

monounsaturated fatty acid

FIGURE 1 | The structure and other basic information of nervonic acid.

exceptional effect of NA in promoting the repair and regeneration of nerve fibers in damaged brain tissues (Sinclair and Crawford, 1972). NA combines with sphingosines via amide bonds to form nervonyl sphingolipids, which are chiefly found in nervous and brain tissues, comprising the white matter and myelin sheath of nerve fibers (Poulos, 1995; Merrill et al., 1997; Martínez and Mougan, 1998). NA plays a vital role in developing and maintaining the brain and biosynthesizing and improving nerve cells. NA is a natural component of maternal milk and can promote infant growth by assisting nervous system development (Farquharson et al., 1996; Ntoumani et al., 2013; Yu et al., 2019). Decreased NA levels are closely associated with a high risk of developing psychotic disorders in individuals (Coupland and Raoul, 2001; Amminger et al., 2012; Vozella et al., 2017), and supplementation with NA is an established effective treatment for symptoms of several neurological diseases, such as demyelinating disorders (Sargent et al., 1994; Vozella et al., 2017; Lewkowicz et al., 2019). NA can also function as a non-competitive inhibitor of human immunodeficiency virus type- 1 reverse transcriptase (HIV-1 RT) in a dose-dependent manner (Kasai et al., 2002). Increasing dietary NA improves energy metabolism in mice and may be an effective strategy for the treatment of obesity and obesity-related complications (Keppley et al., 2020).

Over the past decades, a great number of sharks have been harvested in developed countries to obtain NA due to its market and commercial value. However, international organizations have banned shark fishing, resulting in shortages of NA resources. NA can be chemically synthesized with cis-13-docosenyl methyl ester as a precursor; however, the yield of NA by chemical synthesis is low and there are many by-products (Lei et al., 2013; Fan et al., 2018a). NA is also found in the seed oils of some wild plant species (Tang et al., 2013). However, long growth cycles, limited distributions, and highly variable seed yields have hindered the extraction of NA from natural plant sources (Tang et al., 2013). The construction of NA-producing microorganisms, microalgae, and plants via genetic engineering for nutraceutical and pharmacological applications offers a suitable approach that has attracted widespread attention due to its potential application in the large-scale production of NA (Guo et al., 2009; Taylor et al., 2009; Yuan et al., 2011; Umemoto et al., 2014; Huai et al., 2015; Fillet et al., 2017; Fan et al., 2018a; Xu et al., 2018; Liu et al., 2020). Recently, reviews on the genetic engineering of microorganisms and microalgae for the production of NA have been extensively conducted (Fan et al., 2018a; Li et al., 2019). Plant seed oil products are economical and sustainable industrial feedstock alternatives for shark fishing and traditional chemical synthesis (Leonard, 1994; Jadhav et al., 2005). To increase NA levels in seed oils, genetic engineering approaches have been used to improve existing plant sources and generate new elite cultivars, providing an alternative approach for creating novel cultivars with improved traits and desirable NA contents that cannot be obtained by traditional breeding methods (Giddings et al., 2000). Once a mature system is established in a plant, standard agricultural practices can produce significant amounts of target products, with the cultivation area being the only limitation. However, the use of transgenic plants to produce specific fatty acids (FAs) has not attracted much attention despite the market potential of these biological agents being very considerable. The existing information on the genetic engineering of plants for the production of NA is from isolated studies, and thus the relevant studies need to be thoroughly summarized and discussed to present an integrated and systematic evaluation.

In this review, the available information pertaining to NA biosynthesis, NA resources from plants, and the genetic engineering of NA biosynthesis in oil crops is summarized. Additionally, the factors affecting NA production in genetically engineered oil crops are discussed in detail, and the prospective trends in the engineering of NA are evaluated. Based on the NA biosynthesis pathway and assembly mechanism, new perspectives are highlighted and combined with existing reports on a genetic engineering strategy for the production of NA in plants. This review emphasizes the progress made toward various NArelated topics and explores the limitations and trends, thereby providing integrated and comprehensive insight into the nature of NA production mechanisms during genetic engineering. Furthermore, this report supports further work involving the manipulation of NA production through transgenic technologies and molecular breeding for the enhancement of crop nutritional quality or creation of plant biochemical factories to produce NA for use in nutraceutical, pharmaceutical, and chemical industries.

\section{NA BIOSYNTHESIS AND ASSEMBLY}

The biosynthetic pathway of NA includes de novo FA synthesis in plant plastids and fatty acid elongation (FAE) starting from 
oleic acid (18:1 $\omega-9)$ using four core enzymes located at the endoplasmic reticulum (ER) membrane in the cytoplasm (Figure 2) (Zakim and Herman, 1969; Baud and Lepiniec, 2009). Subsequently, NAs are assembled and stored in the form of triacylglycerols (TAGs) in organisms via the Kennedy pathway (Kennedy, 1961), in addition to transformation from phospholipids to TAGs (Bates et al., 2009) at the ER.

The de novo synthesis of FAs is catalyzed by FA synthases, which form enzyme complexes. It have been reported that FAs linked with an acyl carrier protein (ACP) are elongated to a chain length of $\mathrm{C} 16$ or $\mathrm{C} 18$ and are then released from fatty acyl-A by fatty acyl-ACP thioesterase (Fat A/B) (Figure 2) (Bonaventure et al., 2003; Wu and Xue, 2010; Tjellström et al., 2013). The released FAs are esterified rapidly by long-chain acyl-CoA synthetase (LACS) to prevent them from flowing out of the cells.

After the esterified FAs, including 18:1, are transported to the cytoplasm, FAs are converted into acyl-CoAs by LACS (Salas and Ohlrogge, 2002). Very long-chain fatty acids (VLCFAs, 22-26 carbons) including NA are synthesized in the form of acyl-CoAs by the FAE enzyme complex, which includes four core enzymes located on ER membranes (Haslam and Kunst, 2013). Each cycle of FAE adds two carbon units donated by malonyl-CoA to the acyl chain starting from 18:1 and involves four reactions. Firstly, malonyl-CoA and long-chain acyl-CoA are condensed by 3-ketoacyl-CoA synthase (KCS, sometimes designated as FA elongase, FAE), and secondly, the produced 3-oxoacyl-CoA is reduced by 3-ketoacyl-CoA reductase (KCR) yielding 3-hydroxyacyl-CoA. Then, the action of 3-hydroxacylCoA dehydratase (HCD) results in the generation of 2enoyl-CoA. Finally, 2-enoyl-CoA is reduced by trans-2,3-enoylCoA reductase (ECR) to form elongated acyl-CoA (Figure 2) (Blacklock and Jaworski, 2002; Salas et al., 2005; Huai et al., 2015). In the end, 18:1 is elongated to 24:1 after three cycles of FAE.

These four enzymes have been characterized in Arabidopsis thaliana L. Heynh. (A. thaliana), which revealed that the last three enzymes (KCR, HCD, and ECR) function in all tissues exhibiting VLCFA biosynthesis and possess broad substrate specificity (Zheng et al., 2005; Paul et al., 2006; Bach et al., 2008; Joubès et al., 2008; Beaudoin et al., 2009). In contrast, KCS provides high substrate- and high tissue-specificities for FAE. Protein dynamic simulations revealed a discrepancy in the binding pockets between KCS proteins, which led to the hypothesis that the specificities of different products depend on the shape and size of the substrate-binding pockets (Haslam and Kunst, 2013). Therefore, the expression and activity of KCS determine the amount of synthesized product, and KCS is the rate-limiting enzyme of the VLCFA biosynthesis pathway (Joubès et al., 2008; Millar and Kunst, 2010; Chen et al., 2011; Huai et al., 2015; Yang et al., 2018). Moreover, it is evidenced that the final chain length of VLCFAs depends on the substrate specificity of KCSs (Kunst et al., 1992; Moon et al., 2001; Mietkiewska et al., 2004; Millar and Kunst, 2010; Haslam and Kunst, 2013). Over the past years, progress in understanding the biosynthesis of VLCFAs has been made by cloning and identifying KCS genes in different plants species (James et al., 1995; Lassner and Metz, 1996; Han et al., 2001; Das et al., 2002; Fofana et al., 2004;
Mietkiewska et al., 2004, 2007a,b; Guo et al., 2009; Taylor et al., 2009; Huai et al., 2015; Wang et al., 2018; Yang et al., 2018; Li et al., 2020; Ma et al., 2020).

Fatty acids are mainly stored as TAGs, which are neutral lipids that are a major component of seed oil (Kaup and Thompson, 2002). TAG synthesis begins with the export of free FAs from the plastids followed by the stepwise acylation of these into the sn-1, sn-2, and sn-3 positions of glycerol backbone of glycerol3-phosphate (G3P) (Kennedy, 1961; Lacey and Hills, 1996). The first acylation of G3P at the sn-1 position is catalyzed by glycerol3-phosphate acyltransferase (GPAT) to form lysophosphatidic acid (LPA). The second acylation of LPA at the sn-2 position is catalyzed by lysophosphatidic acid acyltransferase (LPAAT) to form phosphatidic acid (PA). Dephosphorylation of the resultant $\mathrm{PA}$ is then catalyzed by phosphatidic acid phosphatase (PAP) to form DAG. The third acylation reaction, converting DAG to TAG, is catalyzed by diacylglycerol acyltransferase (DGAT) enzymes at the sn-3 position using a fatty acyl-CoA (Figure 2) (Kennedy and Weiss, 1956). The research findings showed that NA can only be incorporated into the sn-1 or sn-3 position instead of sn-2 position of TAGs (Scarth and Tang, 2006; Taylor et al., 2011; Umemoto et al., 2014; Fan et al., 2018b).

Previous studies suggested that MYB and bZIP transcription factors participated in regulating the synthesis of FAs (Yamamoto et al., 2009; Rong et al., 2020), and MYB played important roles in VLCFA biosynthesis particularly (Raffaele et al., 2008). A weighted gene co-expression network analysis in Acer truncatum Bunge (A. truncatum) showed that MYB and bZIP transcription factors were involved in regulating NA biosynthesis (Ma et al., 2020). Recent genome sequencing or transcriptome analysis of A. truncatum, Malania oleifera Chun et S. K. Lee (M. oleifera) or Xanthoceras sorbifolia (X. sorbifolia) species containing rich NA provides important foundations from which to study the molecular mechanisms influencing the NA production (Wang et al., 2018; Yang et al., 2018; Liang et al., 2019; Ma et al., 2019, 2020; Xu et al., 2019) and serves as a support point of NA production by genetic engineering.

\section{NA RESOURCES FROM PLANTS}

In the last 60 years, there has been much interest in obtaining new oil-containing plants for industrial and edible purpose (Jart, 1978). There has been particular focus on NA-containing oil seed plants to explore renewable resources and reduce shark fishing. Thus far, NA has been found in 38 plant species belonging to 31 genera and 13 families, of which eight woody and two herbaceous plants contain at least 4.6\% NA (Ma et al., 2004; Fan et al., 2018a). The amounts of NA are affected by genetic factors and various environmental factors, such as planting pattern and growing conditions (Zheljazkov et al., 2012). Considering the great differences in the content of oil and nerve acid in the seeds of plants, only plants with high oil contents and abundant NA contents are suitable for exploiting and extracting NA (Zheljazkov et al., 2012). The seed oil content, NA and erucic acid (EA, 22:1) content, and NA production limitations of 10 valuable NA-containing plant species from seven families, 


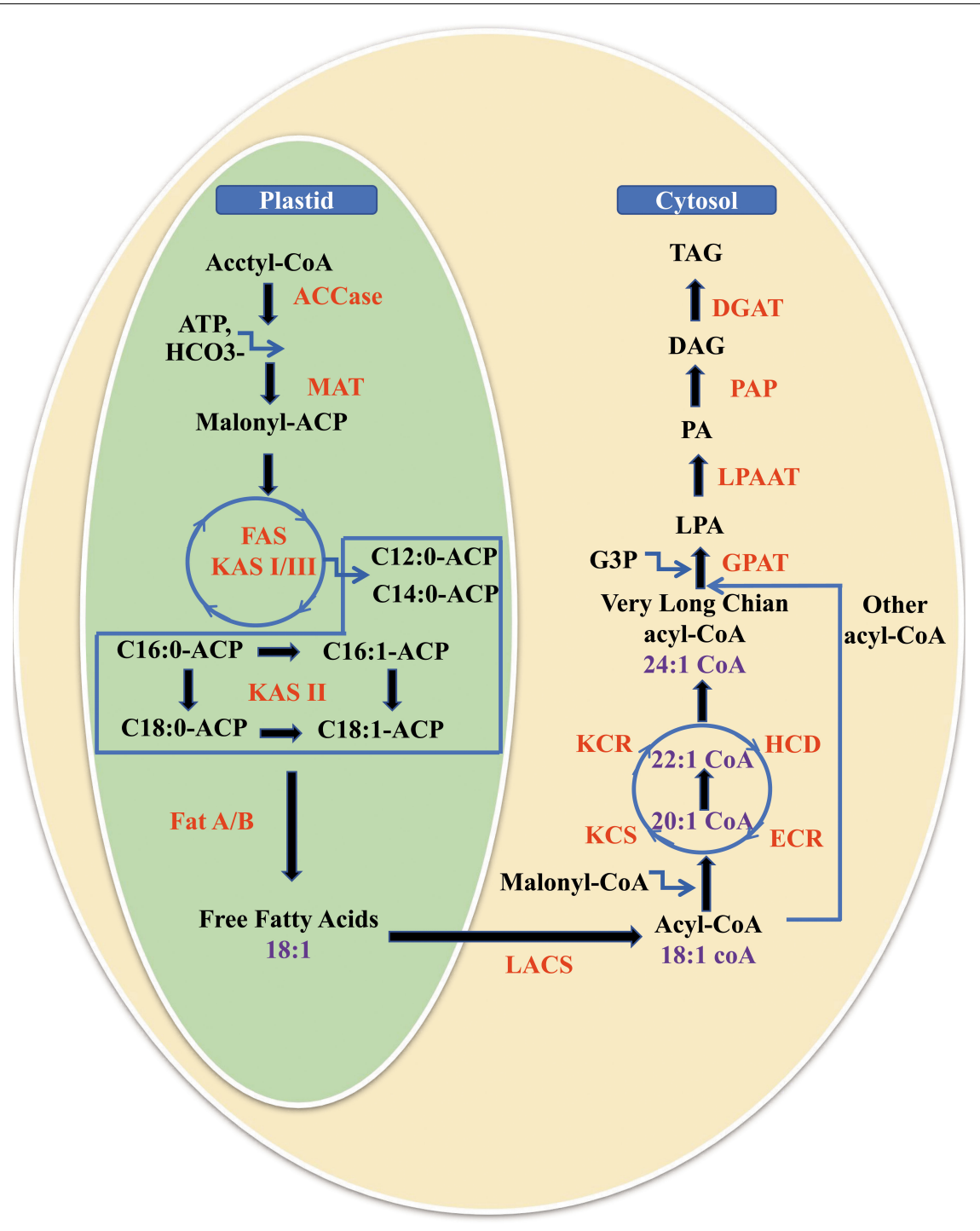

FIGURE 2 | Biosynthesis and accumulation of nervonic acid in plants. It includes the de novo fatty acid synthesis in plant plastids, fatty acid elongation from oleic acid (18:1 $\omega-9)$ to nervonic acid (24:1 $\omega-9)$ for 3 cycles with each cycle adding two carbon units using four core enzymes located at the endoplasmic reticulum membrane in the cytoplasm, and fatty acids storage as triacylglycerols by three key acyltransferases. MAT, malonyl-CoA/ACP transacylase; FAS, fatty acid synthase; KAS, ketoacyl-ACP synthase; Fat A/B, fatty acid thioesterases A/B; LACS, long chain acyl CoA synthetase; FAE, fatty acid elongase; KCS, 3-ketoacyl-CoA synthase; KCR, 3-ketoacyl-CoA reductase; HCD, 3-hydroxacyl-CoA dehydratase; ECR, trans-2,3-enoyl-CoA reductase; GPAT, glycerol-phosphate acyltransferase; G3P, glycerol-3-phosphate; LPA, lysophosphatidic acid; LPAAT, lysophosphatidic acid acyltransferase; PA, phosphatidic acid; PAP, phosphatidic acid phosphatase; DAG, diacylglycerol; DGAT, diacylglycerol acyltransferase; TAG, triacylglycerol.

including four woody and six herbaceous plants, have been listed and compared in Table 1.

Plants with an oil content of more than $10 \%$ have potential industrial value. As indicated in Table 1, nine out of the 10 plant species have oil contents greater than $10 \%$. The high oil content $(\geq 40.1 \%)$ is found in the seeds of $X$. sorbifolia, Ximenia caffra Sond., M. oleifera, and A. truncatum. Given a certain oil content, the ratio of NA to total FAs can best reflect the utilization value of a plant species as a raw material for NA extraction. Eight out of 10 of the plant species have NA contents greater than $2 \%$. The highest NA content $(\geq 63.0 \%)$ is found in the seeds of $M$. oleifera, Cardamine graeca L., and Tropaeolum speciosum Poepp. \& Endl
(T. speciosum). Considering the above two factors, among the 10 plant species, the seeds of M. oleifera, T. speciosum, and Lunaria annua L./Lunaria biennis Moench (L. annua) have both high oil and NA contents and are thus potential candidates for the development of NA products.

Nervonic acid is the major FA in M. oleifera and accounts for $55.7-67.0 \%$ of the total FAs in this plant, the oil content of which ranges from $58.0 \%$ to $63.0 \%$. M. oleifera has the highest content of NA reported thus far in any seed fat. However, $M$. oleifera is a rare and endangered woody oil plant that grows naturally in western Guangxi and southeast Yunnan in China, and its narrow distribution in addition to its protected status limits 
TABLE 1 | Summary of the information including seed oil content, NA and EA content, and NA production limitations on the main plant seeds rich in NA.

\begin{tabular}{|c|c|c|c|c|c|c|c|}
\hline Species & Common name & Oil content (\%) & $\begin{array}{l}\text { NA content of total } \\
\text { fatty acid }(\%)\end{array}$ & $\begin{array}{l}\text { EA content of total } \\
\text { fatty acid }(\%)\end{array}$ & Distribution & Problems & References \\
\hline $\begin{array}{l}\text { Malania oleifera Chun } \\
\text { et S. K. Lee }\end{array}$ & / & $58.0 \sim 63.0$ & $55.7 \sim 67.0$ & $\sim 13.1$ & $\begin{array}{l}\text { Western Guangxi and } \\
\text { southeast Yunnan, } \\
\text { China }\end{array}$ & $\begin{array}{l}\text { Rare, endangered, } \\
\text { narrow distribution }\end{array}$ & $\begin{array}{l}\text { Wang et al., 2006; Tang et al., } \\
\text { 2013; Li et al., 2019; Xu et al., } \\
\text { 2019 }\end{array}$ \\
\hline Ximenia caffra Sond. & Sour Plum & $40.1 \sim 65.0$ & $5.9 \sim 11.4$ & $\sim 0$ & $\begin{array}{l}\text { Tanzania, Zambia, } \\
\text { Zimbabwe, Botswana, } \\
\text { Namibia, Mozambique } \\
\text { and South Africa }\end{array}$ & $\begin{array}{l}\text { Lignoceric acid needs } \\
\text { to be separated from } \\
\text { NA }\end{array}$ & $\begin{array}{l}\text { Lee, 1973; Venter and Venter, } \\
\text { 1996; Chivandi et al., } 2008\end{array}$ \\
\hline Acer truncatum Bunge & Purpleblow maple & $45.0 \sim 48.0$ & $3.9 \sim 7.8$ & $\sim 17.0$ & $\begin{array}{l}\text { North China, Japan, } \\
\text { and Korea, North } \\
\text { America and Europe }\end{array}$ & $\begin{array}{l}\text { Eight to ten years to } \\
\text { maturity }\end{array}$ & $\begin{array}{l}\text { Appelqvist, 1976; Jart, 1978; } \\
\text { Taylor et al., 2009; Qiao et al., } \\
\text { 2018; Ma et al., 2019, } 2020\end{array}$ \\
\hline $\begin{array}{l}\text { Xanthoceras sorbifolia } \\
\text { (Xanthoceras } \\
\text { sorbifolium Bunge) }\end{array}$ & Yellowhorn & $63.3 \sim 69.5$ & $2.0 \sim 2.6$ & $8.3 \sim 8.5$ & $\begin{array}{l}\text { North and Northeast } \\
\text { China }\end{array}$ & $\begin{array}{l}\text { Narrow distribution, a } \\
\text { unique species in China }\end{array}$ & $\begin{array}{l}\text { Zhang et al., 2017; Li et al., } \\
\text { 2019; Liang et al., } 2019\end{array}$ \\
\hline Borago officinalis L. & Borage & $30.0 \sim 40.0$ & $\sim 1.5$ & $1.5 \sim 3.5 \%$ & $\begin{array}{l}\text { Originated in Iran and } \\
\text { some Mediterranean } \\
\text { countries of West Asia, } \\
\text { now in almost all over } \\
\text { the world }\end{array}$ & $\begin{array}{l}\text { Seeds shattered when } \\
\text { mature }\end{array}$ & $\begin{array}{l}\text { Appelqvist, 1976; Jart, 1978; } \\
\text { El-Din and Hendawy, 2010; } \\
\text { Hashemian et al., } 2010\end{array}$ \\
\hline Cannabis sativa L. & Hemp & $26.3 \sim 37.5$ & $3.0 \sim 8.0$ & $1.0 \sim 14.0$ & $\begin{array}{l}\text { Originated in India, } \\
\text { Bhutan and Central } \\
\text { Asia, now in various } \\
\text { countries }\end{array}$ & $\begin{array}{l}\text { Risk of drug harm } \\
\text { seriously restricts the } \\
\text { cultivation }\end{array}$ & $\begin{array}{l}\text { Appelqvist, 1976; Jart, 1978; } \\
\text { Kriese et al., } 2004\end{array}$ \\
\hline Cardamine graeca L. & Bittercress & $12.0 \sim 13.0$ & $45.0 \sim 54.0$ & $9.3 \sim 10.0 \%$ & $\begin{array}{l}\text { Mediterranean } \\
\text { countries }\end{array}$ & $\begin{array}{l}\text { Narrow red soil } \\
\text { requirements, seed } \\
\text { shattering }\end{array}$ & Jart, 1978; Taylor et al., 2009 \\
\hline $\begin{array}{l}\text { Lunaria annua/Lunaria } \\
\text { biennis L. }\end{array}$ & Honesty/money plant & $25.0 \sim 35.0$ & $14.0 \sim 24.2$ & $43.0 \sim 50.0$ & Europe to West Asia & $\begin{array}{l}\text { A poor-yielding biennial, } \\
\text { seed shattering }\end{array}$ & $\begin{array}{l}\text { Mastebroek and Marvin, 2000; } \\
\text { Taylor et al., 2009; Dodos et al. } \\
2015\end{array}$ \\
\hline $\begin{array}{l}\text { Tropaeolum speciosum } \\
\text { Poepp. \& Endl. }\end{array}$ & Flame Flower & $12.3 \sim 26.0$ & $40.0 \sim 45.4$ & $\sim 17.0$ & $\begin{array}{l}\text { Rare plant growing in } \\
\text { Chile }\end{array}$ & $\begin{array}{l}\text { Difficult to obtain seeds } \\
\text { and reproduce }\end{array}$ & $\begin{array}{l}\text { Litchfield, 1970; Taylor et al., } \\
\text { 2009; Li et al., } 2019\end{array}$ \\
\hline Tropaeolum majus L. & Nasturtium & $6.0 \sim 10.0$ & $1.0 \sim 2.0$ & $75.0 \sim 80.0$ & $\begin{array}{l}\text { Originated in South } \\
\text { America Peru, Brazil } \\
\text { and China, now in } \\
\text { temperate areas over } \\
\text { the world }\end{array}$ & $\begin{array}{l}\text { Low oil content, difficult } \\
\text { to obtain seeds and } \\
\text { reproduce }\end{array}$ & Taylor et al., 2009 \\
\hline
\end{tabular}

$N A$, nervonic acid; EA, erucic acid. 
its development and industrialization (Wang et al., 2006; Tang et al., 2013; Li et al., 2019; Xu et al., 2019). T. speciosum, a unique perennial herbaceous plant species from Chile, has a seed oil content in the range of $12.3 \sim 26.0 \%$, with NA remarkably constituting $40.0 \sim 45.4 \%$ of the total FA content. However, its seeds are difficult to obtain and reproduce (Litchfield, 1970; Taylor et al., 2009; Li et al., 2019). L. annua is a biennial herbaceous oil crop that is considered as a niche crop beyond its ornamental value in many countries. The oil content of its seeds is $25 \% \sim 35 \%$, with NA accounting for $14.0 \sim 24.2 \%$ of the total FA content but with EA constituting up to $50 \%$. The seed yields of L. annua vary greatly (800-2000 kg/ha), and seed shattering and the associated harvesting difficulties are long-standing problems (Mastebroek and Marvin, 2000; Taylor et al., 2009; Dodos et al., 2015). In addition, due to its high EA content, L. annua oil cannot meet the nutraceutical and pharmaceutical NA oil requirements of a high NA content but very low EA $(<5 \%)$ content, as diets rich in EA have toxic effects on the heart (Bettger, 2000; Das et al., 2002; Taylor et al., 2009).

There are three key and complex issues for NA production from oil seeds. First, some species suffer from highly variable seed yields, and seeds are prone to shattering when matured and may fall to the ground in the process of harvesting. Second, some species are only distributed in specific areas, which restricts their wide application. Third, some seed oils require the removal of erucic or lignoceric acid by distillation or other expensive methods before they can be used in health applications. Therefore, although a number of species present excellent oil or NA contents, only L. annua and A. truncatum are considered niche species in practice (Ma et al., 2019, 2020), and the other plant species must be further researched to address the current NA extraction inefficiencies. Genetic modification may thus be an excellent approach for the mass production of NA.

\section{GENETIC ENGINEERING OF NA BIOSYNTHESIS IN OIL CROPS}

Nervonic acid is not present in the main cultivated vegetable oil crops (e.g., soybean, rapeseed, sunflower), and the low proportion of NA in natural oilseeds limits its production (Taylor et al., 2009; Li et al., 2019). Breeding programs have been intermittently ongoing in Europe to develop annual types of L. annua aiming to achieve increased oilseed production thus higher NA production, but the results have been less than optimal (Mastebroek and Marvin, 2000). The genetic engineering of oil crops for NA production has thus drawn increasing interest. Genetic engineering provides an alternative method for developing novel varieties with improved traits and desirable characteristics that cannot be achieved by traditional breeding approaches (Giddings et al., 2000). Many studies have shown that the expression of a recombinant KCS in plant hosts alters the seed oil VLCFA contents (Ghanevati and Jaworski, 2001; Das et al., 2002; Mietkiewska et al., 2004, 2007a,b, 2008; Kanrar et al., 2006), and thus the use of KCS or other genes from the NA biosynthesis pathway for increasing NA contents in seed oils via genetic engineering offers a potential effective strategy.
There have been limited attempts to improve NA contents via genetic engineering in oil crops thus far, though some remarkable success has been achieved through the heterologous expression of KCS in transgenic oilseeds. A general comparison of the various transgenic seeds of NA oils is provided in Table 2. Guo et al. (2009) identified the KCS gene from L. annua (LaKCS). The expression of LaKCS in yeast led to the biosynthesis of NA in transgenic yeast, which is not normally present in wild-type yeast cells. The expression of LaKCS in A. thaliana and a high-EA Brassica crop Brassica carinata (B. carinata) under the control of the seed-specific promoter napin led to a 30-40-fold increase in the NA content in transgenic $A$. thaliana and 7-10-fold increase in the NA content in transgenic $B$. carinata in comparison to the wild-type. The highest NA content in transgenic B. carinata offspring was $30 \%$, whereas it was $2.8 \%$ in the wild plant and $20 \%$ in L. annua; however, the EA content in this best transgenic B. carinata line was $25 \%$, whereas it was $35.8 \%$ in the wild plant and $44 \%$ in L. annua (Guo et al., 2009).

The KCS gene isolated from C. graeca (CgKCS) was transferred in yeast, which resulted in the biosynthesis of NA in transgenic yeast (Taylor et al., 2009). The expression of CgKCS in A. thaliana, B. carinata, and high-EA Brassica napus (B. napus) under the control of the seed-specific promoter napin resulted in a 35-55-fold increase in NA content in transgenic A. thaliana, a 15 -fold increase in NA content in transgenic B. carinata, and a 28-fold increase in transgenic $B$. napus in comparison to the wild-type. The maximum NA content in the $B$. carinata transformant reached $44 \%$, whereas it was $2.9 \%$ in the wild plant and $46 \%$ in C. graeca; however, the EA content in the B. carinata transformant was only $5.6 \%$, whereas it was $56.1 \%$ in the wild plant and 10\% in C. graeca (Taylor et al., 2009).

The MoKCS11 gene isolated from M. oleifera was expressed in A. thaliana, high-EA B. napus and Camelina sativa (L.) Crantz. (C. sativa) under the control of the seed-specific promoter phaseolin resulted in 5\% NA accumulation in transgenic A. thaliana, no expected increase in NA content in transgenic high-EA B. napus, and $2.5 \%$ NA accumulation in transgenic C. sativa (Li et al., 2020). MoKCS11 may not synthesize NA in $B$. napus, even though it has abundant EA as the direct substrate of NA. Overexpression of MoKCS11 results in similar level of NA accumulation in $A$. thaliana and $C$. sativa probably because there is a similar and rich proportion of 20:1 in their seeds and MoKCS11 may have a substrate preference for 20:1 instead of EA in planta (Li et al., 2020).

The above research attempted to overexpress KCS to increase the NA content. To understand the impact of KCR, HCD, and ECR in the FAE enzyme complex on NA production, Huai et al. (2015) systematically evaluated the combinatorial effects of KCR, HCD, and ECR with KCS on NA production. LaKCS and AtKCR, and AtHCD and AtECR from A. thaliana were used for the assessment. Five single gene or gene combinations, including LaKCS alone, LaKCS with AtKCR, LaKCS with AtHCD, LaKCS with $A t E C R$, and LaKCS with AtKCR and AtHCD, driven by the seed-specific soybean glycinin-1 or oleosin promoter, were overexpressed in C. sativa. The NA content in the transgenic C. sativa seed oil increased from null to $6-12 \%$ in the LaKCS transgenic lines. However, the NA content did not increase 
TABLE 2 | Comparison of the research on improving the NA content by means of genetic engineering in oil crops.

\begin{tabular}{|c|c|c|c|c|c|c|c|c|c|}
\hline Gene & Donor species & $\begin{array}{l}\text { NA/EA content of } \\
\text { donor species } \\
(\%)\end{array}$ & $\begin{array}{l}\text { Receptor } \\
\text { species }\end{array}$ & $\begin{array}{l}\text { NA/EA content of } \\
\text { control }(\%)\end{array}$ & Strategy & $\begin{array}{l}\text { NA/EA content of } \\
\text { transgenic receptor } \\
\text { species }(\%)\end{array}$ & Fold change & $\begin{array}{l}\text { Substrate in WT } \\
\text { and KCS activity }\end{array}$ & References \\
\hline \multirow[t]{3}{*}{ LaKCS } & Lunaria annua & $20 / 44$ & $\begin{array}{l}\text { Yeast } \\
\text { (Saccharomyces } \\
\text { cerevisiae) }\end{array}$ & 0/0 & GAL1:LaKCS & $\begin{array}{l}\text { Can catalyze NA/EA } \\
\text { synthesis, EA > NA }\end{array}$ & Increase & $\begin{array}{l}\text { Low EA substrate } \\
\text { in WT, KCS activity: } \\
\text { 20 30-fold Higher }\end{array}$ & $\begin{array}{l}\text { Guo et al., } \\
2009\end{array}$ \\
\hline & & & $\begin{array}{l}\text { Arabidopsis } \\
\text { thaliana }\end{array}$ & $\begin{array}{c}0.19 \pm 0.01 / \\
2.0 \pm 0.2\end{array}$ & Napin:LaKCS & $\begin{array}{l}4.3 \pm 0.5 \text { (the best } \\
\text { offspring line } \\
7.6) / 13.8 \pm 0.8\end{array}$ & $\begin{array}{l}30 \sim 40 \text {-fold } \\
\text { increase/sevenfold } \\
\text { increase }\end{array}$ & $\begin{array}{l}\text { Low EA substrate } \\
\text { in WT }\end{array}$ & \\
\hline & & & Brassica carinata & $\begin{array}{l}2.8 \pm 0.1 / \\
35.8 \pm 1.9\end{array}$ & & $\begin{array}{l}19.5 \pm 3.8 \text { (the best } \\
\text { offspring line } 30) / \\
29.0 \pm 2.6\end{array}$ & $\begin{array}{l}\text { 7 10-fold } \\
\text { increase/1.2-fold } \\
\text { decrease }\end{array}$ & $\begin{array}{l}\text { High EA substrate } \\
\text { in WT }\end{array}$ & \\
\hline \multirow[t]{4}{*}{ CgKCS } & Cardamine graeca & $46 / 10$ & $\begin{array}{l}\text { Yeast } \\
\text { (Saccharomyces } \\
\text { cerevisiae) }\end{array}$ & 0/0 & GAL1:CgKCS & $\begin{array}{l}\text { Can catalyze NA/EA } \\
\text { synthesis, EA } \approx N A\end{array}$ & Increase & $\begin{array}{l}\text { Low EA substrate } \\
\text { in WT, KCS activity: } \\
\text { 10 42-fold Higher }\end{array}$ & $\begin{array}{l}\text { Taylor et al., } \\
2009\end{array}$ \\
\hline & & & $\begin{array}{l}\text { Arabidopsis } \\
\text { thaliana }\end{array}$ & $0.2 / 2$ & Napin:CgKCS & $7 \sim 11 / 6 \sim 8$ & $\begin{array}{l}35 \sim 55 \text {-fold } \\
\text { increase/3 4-fold } \\
\text { increase }\end{array}$ & $\begin{array}{l}\text { Low EA substrate } \\
\text { in WT }\end{array}$ & \\
\hline & & & Brassica carinata & $\begin{array}{l}2.9 \pm 0.1 / \\
38.5 \pm 0.4\end{array}$ & & $\begin{array}{l}42.2 \pm 1.3 \text { (the best } \\
\text { offspring line } 44 \text { )/ } \\
5.6 \pm 0.8\end{array}$ & $\begin{array}{l}15 \text {-fold } \\
\text { increase/6.9-fold } \\
\text { decrease }\end{array}$ & $\begin{array}{l}\text { High EA substrate } \\
\text { in WT }\end{array}$ & \\
\hline & & & Brassica napus & $\begin{array}{l}1.1 \pm 0.0 / \\
56.1 \pm 0.0\end{array}$ & & $\begin{array}{l}31.3 \pm 5.0 / \\
21.6 \pm 4.0\end{array}$ & $\begin{array}{l}\text { 28-fold } \\
\text { increase/2.6-fold } \\
\text { decrease }\end{array}$ & $\begin{array}{l}\text { High EA substrate } \\
\text { in WT }\end{array}$ & \\
\hline LaKCS & Lunaria annua & $20 / 44$ & Camelina sativa & 0/3.4 & Gly-P:LaKCS & $\begin{array}{l}5.9 \sim 12.0 / \\
10.5 \sim 11.6\end{array}$ & $\begin{array}{l}\text { Increase/3.3-fold } \\
\text { increase }\end{array}$ & $\begin{array}{l}\text { Low EA substrate } \\
\text { in WT }\end{array}$ & $\begin{array}{l}\text { Huai et al., } \\
2015\end{array}$ \\
\hline $\begin{array}{l}\text { LaKCS and } \\
\text { AtKCR }\end{array}$ & $\begin{array}{l}\text { Lunaria annua and } \\
\text { Arabidopsis } \\
\text { thaliana }\end{array}$ & $20 / 44$ and $0.2 / 2$ & & & $\begin{array}{l}\text { Gly- } \\
\text { P:LaKCS + Gly- } \\
\text { P:AtKCR }\end{array}$ & $\begin{array}{l}11.3 \sim 11.8 / \\
11.2 \sim 11.5\end{array}$ & $\begin{array}{l}\text { Increase/3.3-fold } \\
\text { increase }\end{array}$ & $\begin{array}{l}\text { Low EA substrate } \\
\text { in WT }\end{array}$ & \\
\hline $\begin{array}{l}\text { LaKCS and } \\
\text { AtHCD }\end{array}$ & $\begin{array}{l}\text { Lunaria annua and } \\
\text { Arabidopsis } \\
\text { thaliana }\end{array}$ & $20 / 44$ and $0.2 / 2$ & & & $\begin{array}{l}\text { Gly- } \\
\text { P:LaKCS + Gly- } \\
P: A t H C D\end{array}$ & $\begin{array}{l}10.7 \sim 12.9 / \\
11.2 \sim 11.5\end{array}$ & $\begin{array}{l}\text { Increase/3.3-fold } \\
\text { increase }\end{array}$ & $\begin{array}{l}\text { Low EA substrate } \\
\text { in WT }\end{array}$ & \\
\hline $\begin{array}{l}\text { LaKCS and } \\
\text { AtECR }\end{array}$ & $\begin{array}{l}\text { Lunaria annua and } \\
\text { Arabidopsis } \\
\text { thaliana }\end{array}$ & $20 / 44$ and $0.2 / 2$ & & & $\begin{array}{l}\text { Gly- } \\
\text { P:LaKCS + Gly- } \\
\text { P:AtECR }\end{array}$ & $\begin{array}{l}9.9 \sim 10.0 / \\
11.9 \sim 12.5\end{array}$ & $\begin{array}{l}\text { Increase/3.6-fold } \\
\text { increase }\end{array}$ & $\begin{array}{l}\text { Low EA substrate } \\
\text { in WT }\end{array}$ & \\
\hline $\begin{array}{l}\text { LaKCS, AtKCR } \\
\text { and AtHCD }\end{array}$ & $\begin{array}{l}\text { Lunaria annua and } \\
\text { Arabidopsis } \\
\text { thaliana }\end{array}$ & $20 / 44$ and $0.2 / 2$ & & & $\begin{array}{l}\text { Gly- } \\
\text { P:LaKCS + Dleo- } \\
\text { P:AtKCR + Gly- } \\
\text { P:AtHCD }\end{array}$ & $\begin{array}{l}10.0 \sim 10.8 / \\
11.4 \sim 12.1\end{array}$ & $\begin{array}{l}\text { Increase/3.5-fold } \\
\text { increase }\end{array}$ & $\begin{array}{l}\text { Low EA substrate } \\
\text { in WT }\end{array}$ & \\
\hline \multirow[t]{3}{*}{ MoKCS11 } & Malania oleifera & $40 / 15$ & $\begin{array}{l}\text { Arabidopsis } \\
\text { thaliana }\end{array}$ & $0.2 / 2.4$ & Phaseolin:MoKCS11 & $5.0 / 8.0$ & $\begin{array}{l}25 \text {-fold } \\
\text { increase/3.3-fold } \\
\text { increase }\end{array}$ & $\begin{array}{l}\text { Low EA substrate } \\
\text { in WT }\end{array}$ & $\begin{array}{l}\text { Li et al., } \\
2020\end{array}$ \\
\hline & & & Brassica napus & $1.2 / 24.4$ & & $1.2 / 31.2$ & $\begin{array}{l}\text { no increase/1.3-fold } \\
\text { increase }\end{array}$ & $\begin{array}{l}\text { High EA substrate } \\
\text { in WT }\end{array}$ & \\
\hline & & & Camelina sativa & $0.5 / 3.7$ & & $2.5 / 5.1$ & $\begin{array}{l}5 \text {-fold increase } / 1.4 \text {-fold } \\
\text { increase }\end{array}$ & $\begin{array}{l}\text { Low EA substrate } \\
\text { in WT }\end{array}$ & \\
\hline
\end{tabular}

NA, nervonic acid; EA, erucic acid; GAL1, galactose-inducible GAL1 promoter; Napin, seed-specific napin promoter; Gly-P, seed-specific soybean glycinin-1 promoter; Dleo-P, strong seed specific soybean oleosin promoter; WT, wild-type. 
further when one or two additional genes in the FAE enzyme complex were expressed in the mature seeds. At the early stage of seed development, the NA contents from the LaKCS, AtKCR, and AtHCD co-expressing lines were significantly higher than that of the LaKCS transgenic lines, while the ultimate NA content did not change significantly. The maximum NA content of $12.9 \%$ was attained in the C. sativa LaKCS and AtHCD co-expressed line, whereas it was $0 \%$ in the wild plant, $20 \%$ in L. annua, and $0.2 \%$ in A. thaliana. However, the EA content in this best transgenic line was $11.5 \%$, whereas it was $3.4 \%$ in the wild plant, $44 \%$ in L. annua, and $2 \%$ in A. thaliana (Huai et al., 2015).

\section{FACTORS AFFECTING NA PRODUCTION IN GENETICALLY ENGINEERED OIL CROPS}

An understanding of the regulatory features controlling NA biosynthesis is critical for the future engineering of oilseed crops for increased NA production. Several factors influence the application of transgenic techniques to promote the efficient improvement of NA in oil-producing plants.

\section{KCS Is Decisive Instead of KCR, HCD, and ECR}

Over the past few decades, it has been demonstrated that KCS is a rate-limiting enzyme and regulating the expression of specific KCS influences the final chain length and contents of VLCFAs (Cahoon, 2000; Han et al., 2001; Mietkiewska et al., 2004, 2007a,b; Haslam and Kunst, 2013). Huai et al. (2015) further confirmed this conclusion specifically regarding NA synthesis, in that the final amount of NA product is determined by the amount of KCS rather than that of KCR, HCD, and ECR (Table 2).

\section{Appropriate KCS Enzymes Need to Be Used}

Nervonic acid is synthesized at the expense of EA and 20:1 FA. KCS genes from different sources exhibit distinct substrate specificity and thus possess a differential ability and efficiency to convert substrates to NA, even in the same receptor species. B. carinata transformed with LaKCS produced oil with $30 \% \mathrm{NA}$, but the EA content was still 29.0\%. When transformed with the CgKCS, B. carinata produced oil with up to $44 \% \mathrm{NA}$ and a significantly reduced EA level of 5.6\% (Table 2). Since EA is the predominant VLCFA in wild-type $B$. carinata, this suggests that CgKCS performed better than LaKCS in transgenic $B$. carinata to convert EA to NA.

Similarly, A. thaliana transformed with LaKCS produced oil with 7.6\% NA and $13.8 \% \mathrm{EA}$, while transformation with $\mathrm{CgKCS}$ produced oil with 7-11\% NA and 6-8\% EA (Guo et al., 2009; Taylor et al., 2009; Table 2). In A. thaliana LaKCS transgenics where 20:1 substrate is the predominant VLCFA in the wildtype, the proportion of EA is about threefold higher than that of NA (Guo et al., 2009). This indicated that these KCS genes have a strong capacity to convert 20:1 to EA instead of EA to NA. Notably, in A. thaliana CgKCS transgenics, CgKCS has the ability to convert 20:1 into EA and to produce NA using EA as the precursor, so that NA is as prominent a product $(7-11 \%)$ as EA (6-8\%) in the transgenic oilseed (Taylor et al., 2009; Table 2). This indicates that CgKCS exhibits a strong capacity to convert 20:1 into EA as well as to convert EA into NA. For another example, the overexpression of KCS genes from B. napus (Han et al., 2001), Tropaeolum majus L. (Mietkiewska et al., 2004), Brassica. juncea (Kanrar et al., 2006), Crambe abyssinica (C. abyssinica) (Mietkiewska et al., 2007a), and M. oleifera (Li et al., 2020) in high-EA Brassicaceae results in significantly improved EA, but not NA proportions, as these KCS genes elongate 20:1-CoA more effectively. In addition, the Teesdalia nudicaulis (L.) W. T. Aiton KCS preferentially elongates 18:1 substrates in yeast and A. thaliana (Mietkiewska et al., 2007b). Thus, the substrate selectivity of the KCS enzyme is indeed relatively promiscuous, and similar results have been observed in experiments where LaKCS and CgKCS are ectopically expressed in yeast, which indicated rather loose specificity via the detection of each of three labeled substrates 18:1, 20:1, and 22:1 (Guo et al., 2009; Taylor et al., 2009).

The evolution of KCS genes has resulted in their functional divergence and renovation, and thus a wide range of substrate specificities and product diversities exist (Fan et al., 2018a). Due to the membrane-binding properties of the KCS protein, our understanding of the nature and regulation of this enzyme is still limited, and the substrate specificity of KCS needs be investigated (Puyaubert et al., 2005a,b). In present studies, KCS genes have been selected chiefly from donor species that have high NA levels and have been considered as niche crops but with limited success because of uneconomy. For instance, C. graeca has narrow red soil requirements, a low oil content, and seeds that are prone to shattering (Jart, 1978; Taylor et al., 2009), and $L$. annua is a poor-yielding biennial with a low oil content and shatter-prone seeds (Mastebroek and Marvin, 2000; Guo et al., 2009; Dodos et al., 2015; Huai et al., 2015). In the future, numerous KCS proteins for VLCFA biosynthesis need to be identified in plant resources with high NA contents, and their functions, especially the mechanisms by which KCS affects NA production, need to be verified. Since NA is particularly abundant in M. oleifera, T. speciosum, and A. truncatum, new KCS enzymes discovered and identified from these plants may constitute good choices in NA genetic engineering (Ma et al., 2004, 2019, 2020; Xu et al., 2019).

\section{Seed-Specific Promoters, High Transgene Copy Numbers and/or the Optimum Genomic Integration Sites, and High KCS Activity All Contribute to Increased Proportions of NA}

The overexpression of KCS genes with a strong seed-specific promoter in genetically engineered oilseed plants is a key avenue for improving NA production by increasing the expression of KCS in the seeds specifically and decreasing the potential risk of the constitutive expression of KCS genes. The seed-specific napin promoter (Guo et al., 2009; Taylor et al., 2009), the seed-specific soybean glycinin-1 promoter (Huai et al., 2015), and the strong 
seed-specific soybean oleosin promoter (Huai et al., 2015) were used to drive KCS expression in A. thaliana (Guo et al., 2009; Taylor et al., 2009), B. carinata (Guo et al., 2009; Taylor et al., 2009), B. napus (Taylor et al., 2009) or C. sativa (Huai et al., 2015), leading to 7-55-fold increases in NA content (Table 2).

The transcription levels of different genes under the control of the same promoter are quite different and the same gene may exhibit a similar transcription level under the regulation of different seed-specific promoters (Huai et al., 2015). That is to say, the level of gene transcription is also limited by the gene property, even sometimes by the promoter as we have known. The promoter affects the gene expression level, but the maximum expression level is determined by the gene. The stability and decay rate of individual mRNA molecules are affected by gene sequence GC\%, DNA sequence elements, or the secondary structure of mRNAs, and so some genes are high-expression genes and others are not.

The increased NA phenotype of LaKCS transgenic lines was found to be associated with multiple LaKCS transgene copies, which led to higher transcript intensities, though the correlation was not necessarily linear (Guo et al., 2009). Similarly, research on ACP thioesterase transgenes at the level of the major target FA confirmed that in order to achieve the maximum expression levels of target FA, it is important to select high copy numbers and/or the optimal genomic integration sites for improving transgenic oil quality (Tang et al., 2003).

Upon providing 14C-22:1-CoA as a substrate, the KCS activity from the developing seeds of transgenic LaKCS-B. carinata and $C g K C S-B$. carinata was 20-30-fold and 10-42-fold higher, respectively, than the barely detectable erucoyl-CoA elongation activity exhibited by the wild-type control plants (Guo et al., 2009; Taylor et al., 2009; Table 2). Furthermore, the 22:1-CoA KCS activity levels in the developing $B$. carinata seeds were well-correlated with the associated LaKCS or CgKCS transcript signals according to northern blot analysis (Guo et al., 2009; Taylor et al., 2009).

\section{Sufficient Specific Substrate Is Available in Receptor Species}

In addition to KCS specificity and the amount of KCS expression, the availability and magnitude of specific substrates of KCS enzymes is also a key factor influencing the efficiency of chain elongation and ultimately the proportion of the NA produced by genetic engineering (Guo et al., 2009; Taylor et al., 2009; Huai et al., 2015; Yu et al., 2017).

Considering that EA is the major precursor of NA, if a highEA crop contains only little NA in its seed oil due to the absence of KCS with a strong capacity to convert EA to NA, then this crop is a good option as an acceptor species for NA genetic engineering via the transformation of an appropriate $K C S$ gene. This is supported by studies where the KCS genes from L. annua (Guo et al., 2009; Huai et al., 2015) and C. graeca (Taylor et al., 2009) have been overexpressed in B. carinata (Guo et al., 2009; Taylor et al., 2009) and B. napus (Taylor et al., 2009) with high EA, resulting in a significant improvement in NA proportion.
Heterologous expression of the LaKCS gene in A. thaliana, $B$. carinata, and $C$. sativa increased the NA content to $4.3-$ $7.5 \%, 19.5-30 \%$, and $5.9-12.0 \%$, respectively (Guo et al., 2009; Huai et al., 2015; Table 2). A similar phenomenon has also been observed in other studies. Heterologous expression of the CgKCS gene in A. thaliana, B. carinata, and high-EA B. napus increased the NA content to $7-11,42.2$, and $31.3 \%$, respectively (Taylor et al., 2009; Table 2). The NA quantities in the seed oil from engineered $A$. thaliana and C. sativa were low, and these plants have lower EA contents of 2 and 3.4\%, respectively, in their wildtype seeds (Guo et al., 2009; Taylor et al., 2009; Huai et al., 2015; Table 2). In contrast, the NA contents in seed oil of engineered $B$. carinata and high-EA B. napus were significantly enhanced, and these plants have much higher EA levels of 35.8 and $56.1 \%$ for elongation in their wild-type seeds (Guo et al., 2009; Taylor et al., 2009; Table 2). Therefore, the proportion of EA substrate in the oilseed may limit the degree of NA synthesis. This indicates that not only KCS specificity, but also substrate availability, exerts a certain control on NA production.

The availability of sufficient specific substrates such as EA may exist in natural receptor species or be created via transgenes. It was reported that EA can accumulate in C. abyssinica by reducing the desaturase activity by co-expressing the LdLPAAT, BnFAE1, and CaFAD2-RNAi genes. Therefore, more 18:1 can enter the FA extension pathway, resulting in a $28.0 \%$ higher EA level than that in the wild-type ( $\mathrm{Li}$ et al., 2012). This strategy of creating receptors with high EA substrates can be used to encourage NA accumulation in genetic engineering.

\section{Other Optimal Participants in VLCFA Elongation Are Available in Receptor Species}

It is not necessarily the case that a high abundance of EA leads to higher NA production. The NA content in CgKCS transgenic B. carinata, with a lower EA substrate level of $35.8 \%$ in the wild-type seeds, reached $42.2 \%$, while an NA content of $31.3 \%$ was achieved in CgKCS transgenic B. napus, which has a high EA level of $56.1 \%$ (Taylor et al., 2009; Table 2). The difference appears to be more complex than simply KCS substrate availability. Indeed, the higher level of EA in B. napus could not necessarily be translated into NA efficiently, which may be a result of four possibilities. First, even if there is a strong napin-driven overexpression of $C g K C S$, the KCS of native plants still has a considerable contribution to FA products, which reflects a varying number of elongation cycles starting from various indigenous 18:1 or VLC primers. Second, the lower conversion of EA to NA in high-EA B. napus is possibly limited by the activities of the other three enzymes of the elongase system. Third, NA synthesis in high-EA $B$. napus may lack other rate-limiting elongation substrates such as malonyl-CoA, in which case it is required to co-express a cytosolic acetyl-CoA carboxylase to facilitate elongation. Fourth, there may also be inadequate reductants (NADH and/or NADPH) for the second or fourth enzymatic steps in the elongation complex. The variable effects of the reliance of KCS gene expression on the receptor 
plant have significant implications for the selection of suitable receptor platforms.

\section{There Is Efficient Assembly of NA to More TAG Sites}

Compared with B. carinata, the considerably less than complete conversion of EA to NA in B. napus (Taylor et al., 2009; Table 2) may be due to the disadvantages in the selectivities or preferences of acyltransferases with regard to the degree of assembling NA to sn- 1 and/or sn-3 sites of TAGs; therefore, the substrate specificity of the three acyltransferases can be modified to accumulate more NA in the cells.

Nervonic acid can only be incorporated into the sn-1 or sn3 position of TAGs through endogenous acyltransferases, but not into both positions at the same time, and is predicted more likely to be incorporated into sn-3. However, C16 and C18 FA are typically found instead of NA in the sn-2 position in the fungus Mortierella capitata RD000969, microalga Mychonastes afer (Umemoto et al., 2014; Fan et al., 2018b). Similar limitation of further increase NA content also occurs in high-EA B. napus and $B$. carinata and negligible NA is found at the sn-2 position on the glycerol backbone because the ability of endogenous Brassica LPAAT to incorporate nervonoyl moieties into sn-2 position is very low (Scarth and Tang, 2006; Taylor et al., 2011). This bottleneck also limits the content of EA and other VLCFAs as the longer FAs tend to be localized at the sn-1,3 position, which restricts the level of NA, EA or other VLCFAs in the seed oil to a theoretical limit of $66 \%$. One successful study resulted in increases of EA of up to $56 \%$ compared to $45 \%$ in the control via the expression of the yeast SLC1-1 in high-EA B. napus (yeast LPAAT, Zou et al., 1997). However, expressing Limnanthes LPAATs in high-EA $B$. napus only led to an increased proportion of erucoyl moieties at the sn- 2 position of up to $41 \%$, instead of enhancing the total EA content. Given these EA engineering results, it is inferred that NA content is limited by various factors, and the improved ability of LPAAT to incorporate nervonoyl moieties into sn-2 could raise the upper limit but not necessarily enhance the end NA content. In the future, it is more feasible to modificate the substrate specificity of GPAT and LPAAT and co-expressing multiple genes in B. carinata or high-EA B. napus to increase NA levels over $66 \%$ in seed oil (Cahoon et al., 2007; Taylor et al., 2011).

\section{CRUCIFERAE OIL CROPS WITH FAVORABLE ATTRIBUTES ARE IDEAL RECEPTOR SPECIES}

Regarding an ideal receptor platform, there has been special focus on Cruciferae. Many cruciferous seeds are high in oil, and numerous cruciferous oils contain ample VLCFAs, affording a superior basis for the synthesis of high amounts of NA in the seed oil. Contrary to most other oil crops, this family exhibits good growth capability in temperate climates and high harvest yields. Additionally, the transformation efficiency of some cruciferous species is particularly high. Thus, cruciferous oilseed crops with favorable attributes are becoming increasingly popular as industrial platforms for engineering NA oil production.

For example, B. carinata is an attractive receptor species that was used for the expression of LaKCS and CgKCS (Guo et al., 2009; Taylor et al., 2009). B. carinata is resistant to fungal diseases, drought, weeds, and insect pests and is thus suitable for growth in a wide range of regions. It also has a very high yield of 2500-3000 kg/ha (Taylor et al., 2009) and is very easily transformed (at a rate of 25-50\%, Babic et al., 1998). However, high-EA B. napus, which was previously used to express CgKCS for engineering NA oil production, has a yield of only $1500 \mathrm{~kg} / \mathrm{ha}$. In addition, the transformation efficiency of high-EA $B$. napus is typically poorer than that of canola cultivars (Taylor et al., 2009). C. sativa is becoming a popular industrial platform for the production of FA oil by means of genetic engineering ( $\mathrm{Lu}$ et al., 2011; Nguyen et al., 2013; Cahoon, 2014; Carlsson et al., 2014; Iskandarov et al., 2014; Nguyen et al., 2015) and was used to express LaKCS for NA oil production (Huai et al., 2015). This species has the advantages of cold and drought tolerance and low fertilizer requirements and is also distributed widely. Further, it has a short lifecycle (100-120 days) and is amenable to transformation using Agrobacterium-mediated methods (Gugel and Falk, 2006; Pilgeram et al., 2007; Lu and Kang, 2008).

The average oil content of the mature seeds of $C$. graeca is about $13 \%$, and the oil content of $B$. carinata is $38 \%$, which is about $10 \%$ lower than in high-EA B. napus varieties (Taylor et al., 2008). The expression of CgKCS had no adverse effect on oil content (Taylor et al., 2009). The average percentage of NA found in transgenic B. carinata is $42.2 \%$, which is similar to the value of $46 \%$ in C. graeca, but the oil content of $B$. carinata is three times that of $C$. graeca and the yield of $B$. carinata is about 2500-3000 kg/ha (Taylor et al., 2009; Table 2). The projected NA content, seed oil content, and high field seed yields make $C g K C S$ transgenic $B$. carinata lines the best performers among all NA seed sources thus far. However, in order to produce ultrahigh NA in this crucifer as an acceptable new platform crop, the seed oil content of $B$. carinata needs to be significantly improved, which could be achieved through genetic modification, such as overexpressing the Arabidopsis DGAT1 gene (Jako et al., 2001) or the yeast SLC1-1 gene (Zou et al., 1997; Katavic et al., 2001; Taylor et al., 2001).

\section{A SUPERIOR GROWTH ENVIRONMENT AND MANUAL SELECTION CONTRIBUTE TO NA PRODUCTION}

The profiles of the CgKCS transgenic B. carinata lines are from confined field trials (Taylor et al., 2009), while the LaKCS transgenic $B$. carinata lines translate well from greenhouse to field conditions (Katavic et al., 2001; Taylor et al., 2001). In terms of industrial-scale engineering of NA oil production in oil crops, climate, geographical location, and hydrology are all important factors that should be considered, as these factors affect the oil content, yield, and the FA profile, ultimately significantly influencing NA production. Appropriate temperatures, sufficient sunshine, and a good supply of water and fertilizer are generally 
conducive to both the filling of oil seeds as well as oil accumulation. However, temperature extremes and low light, drought, and flooding will greatly reduce the oil content.

Following genetic analysis and gene expression, the best transgenic lines with a high-NA phenotype are manually selected according to the FA profile in each generation, which is conducive to high NA production (Guo et al., 2009; Taylor et al., 2009; Huai et al., 2015). The NA content in transgenic Arabidopsis $\mathrm{T}_{2}$ seed oils expressing the LaKCS was $4.3 \pm 0.5 \%$, and after selection the best line $\mathrm{T}_{3}$ transgenic line had an NA content of $7.6 \%$. The NA content in transgenic $B$. carinata $\mathrm{T} 1$ seed oils expressing LaKCS was $19.5 \pm 3.8 \%$, and following selection, the best NA content in the $\mathrm{T} 2$ transgenic line was $30 \%$ (Guo et al., 2009). On average, the NA content in the CgKCS transgenic B. carinata $\mathrm{T}_{1}$ seed oils was $38 \%$, and after selection, the highest NA level in the $\mathrm{T}_{4}$ transgenic line reached 44\% (Taylor et al., 2009; Table 2).

\section{CONCLUSION AND PERSPECTIVES}

The brain and nervous system are composed of white matter and gray matter. Docosahexaenoic acid (DHA, 22:6) are typical FAs especially concentrated in the gray matter, and NAs are typical FAs of the white matter (Sinclair and Crawford, 1972; Poulos, 1995; Merrill et al., 1997; Martínez and Mougan, 1998; Brenna and Diau, 2007; Weiser et al., 2016). Like DHA, arachidonic acid (eicosatetraenoic acid, ARA, 20:4), eicosapentaenoic acid (EPA, 20:5), and conjugated linoleic acid, NA is a strong candidate for further evaluation as a lipid supplement with brilliant application prospects due to its excellent biofunctions in promoting human health (Coupland and Langley, 1991; Coupland, 1996; Coupland and Raoul, 2001). Higher levels of NA in the diet assist in the formation of the myelin membrane outside the myelinated nerve fibers and also bind to transcription factors and regulate gene expression, thus modulating lipid and energy metabolism (Zheng et al., 2006; Van Meer et al., 2008). While an increasing number of studies have focused on the biological functions of NA, our current understanding of NA is still limited in that systematic and reliable studies on the role of NA in the general population are still lacking and the mechanisms of how dietary and physiological factors affect NA levels and molecular forms in animals and humans need to be specified. Natural or engineered seed oils with enriched NA but very low EA content $(<5 \%)$ could be used as the necessary feedstocks to study health disease models through feeding trials on humans and animals in nutraceutical and pharmaceutical applications (Bettger, 2000). Achieving a balance between NA and EA is thus an important goal. Future NA products aim to develop edible NA oils ${ }^{1}$ and produce dairy products enriched in NA by adding high-NA feed to dairy livestock for human consumption (Bettger, 2000; Bettger et al., 2003), thus providing a healthy alternative to oil or milk powder for enhancing neural development in infants and preventing neurodegenerative diseases.

The use of NA in chemical applications is promising. Lunaria oil containing $14.0-24.2 \%$ NA can be used as an industrial

${ }^{1}$ http://www.bioriginal.com/products/formats.php lubricant (Meier zu Beerentrup and Röbbelen, 1987; Soest, 1994). NA has high potential for the synthesis of nylon 15, provided that there is a low EA in the oil mixture, and NA can be processed into pentadecane diacid for the production of polyesters (Jart, 1978). Nervonoyl-CoA has been identified to be able to produce new wax esters in transgenic Brassica crops as a desired precursor/intermediate (Taylor et al., 2009).

Given these research and application requirements, future research should focus on industrial NA production. Plants, particularly oil crops, are a potential renewable and environmentally friendly resource, the NA yield of which can be improved by regulating the biosynthesis pathways of NA via genetic engineering. CgKCS shows promise for engineering high-NA oil for nutraceutical and pharmaceutical applications. For instance, $C g K C S$ transgenic $B$. carinata produced oil with up to $44 \%$ NA with much reduced EA levels of 5-6\% (Taylor et al., 2009), approaching the acceptable level of 5\% or less EA, rendering this oil suitable for health application trials (Bettger, 2000). The projected NA yield is $160 \mathrm{~g} / \mathrm{kg}$ seed in $C g K C S$ transgenic $B$. carinata, which is higher than the $115 \mathrm{~g} / \mathrm{kg}$ seed in LaKCS transgenic B. carinata, $103 \mathrm{~g} / \mathrm{kg}$ seed in CgKCS transgenic high-EA B. napus, and $98 \mathrm{~g} / \mathrm{kg}$ seed in T. speciosum. Furthermore, LaKCS transgenic B. carinata oil does not meet health requirements due to its high EA contents. In addition to the high seed yields, CgKCS transgenic B. carinata is the best performer among all the NA seed sources, and its oil has been examined in animal disease model systems for nutraceutical and pharmaceutical applications. In addition, the other VLCFAs, including 18:2, 18:3, and 26:1, totaled $25-30 \%$ in the CgKCS transgenic B. carinata (Taylor et al., 2009). If the NA levels approach $80 \%$, the cost of producing these NAs and their derivatives would be substantially reduced to meet the forecasted increase in demand for NA seed oil products for nutraceutical, pharmaceutical, and chemical industries.

Numerous studies have indicated that the accumulation of NA in seed oil is controlled by complex mechanisms (Guo et al., 2009; Taylor et al., 2009, 2011; Huai et al., 2015). High KCS-specificity and activity during seed development and the ability to assemble NA to more TAG sites are necessary steps for increasing NA contents; however, these steps are not sufficient. Rather, additional genes must be inserted to obtain High Erucic Acid Rapeseed (HEAR) cultivars accumulating seed oil with a homogeneous FA composition. In the future, ideal NA production in seed oils can be obtained via the coexpression of multiple genes, including KCS genes that can completely convert substrate to NA, additional genes such as acyltransferase genes that can assemble NA to sn-1,2,3 sites efficiently, and genes that can improve the oil content, in appropriate cruciferous oil crops with enriched substrate, high oil content, and high yield.

\section{AUTHOR CONTRIBUTIONS}

$\mathrm{XZh}$ and FL designed and structured the review. PW and XX collected the information. FL and PW organized the tables. FL 
and XX prepared the figures. FL and XZh wrote and revised the manuscript. GW, XZh, and XZe commented on the manuscript. All the authors read and approved the final manuscript.

\section{FUNDING}

This work was supported by the National Program of Transgenic Variety Development of China (SQ2019ZD080018), the Agricultural Science and Technology Innovation Program of

\section{REFERENCES}

Amminger, G. P., Schäfer, M. R., Klier, C. M., Slavik, J. M., Holzer, I., Holub, M., et al. (2012). Decreased nervonic acid levels in erythrocyte membranes predict psychosis in help-seeking ultra-high-risk individuals. Mol. Psychiatry 17, 1150-1152. doi: 10.1038/mp.2011.167

Appelqvist, L. A. (1976). "Lipids in Cruciferae," in The Biology and the Chemistry of the Cruciferae, eds. J. G. Vaughan and A. J. Macleod (London: Academic Press), 221-277.

Babic, V., Datla, R. S., Scoles, G. J., and Keller, W. A. (1998). Development of an efficient Agrobacterium-mediated transformation system for Brassica carinata. Plant Cell Rep. 17, 183-188. doi: 10.1007/s002990050375

Bach, L., Michaelson, L. V., Haslam, R., Bellec, Y., Gissot, L., Marion, J., et al. (2008). The very-long-chain hydroxy fatty acyl-CoA dehydratase PASTICCINO2 is essential and limiting for plant development. Proc. Natl. Acad. Sci. U.S.A. 105, 14727-14731. doi: 10.1073/pnas.0805089105

Bates, P., Durrett, D., Timothy, P., Ohlrogge, J., and Pollard, B. (2009). Analysis of Acyl fluxes through multiple pathways of triacyiglycerol synthesis in developing soybean embryos. Plant Physiol. 150, 55-72. doi: 10.1104/pp.109.137737

Baud, S., and Lepiniec, L. C. (2009). Regulation of de novo fatty acid synthesis in maturing oilseeds of Arabidopsis. Plant Physiol. Biochem. 47, 448-455. doi: 10.1016/j.plaphy.2008.12.006

Beaudoin, F., Wu, X., Li, F., Haslam, J., Markham, J. E., Zheng, H., et al. (2009). Functional Characterization of the Arabidopsis -Ketoacyl-Coenzyme A Reductase Candidates of the Fatty Acid Elongase. Plant Physiol. 150, 1174-1191. doi: 10.1104/pp.109.137497

Bettger, W. J. (2000). Apparent Transfer Efficiency of Nervonic Acid from Diet to Milk in Dairy Cows and the Subsequent Enrichment of Nervonic Acid in Skim Milk-Based Dairy Products. Special Research Funds 2000. Guelph, ON: University of Guelph.

Bettger, W. J., Dimichelle-Ranalli, E., Dillingham, B., and Blackadar, C. B. (2003). Nervonic acid is transferred from the maternal diet to milk and tissues of suckling rat pups. J. Nutr. Biochem. 14, 160-165. doi: 10.1016/S0955-2863(02) 00280-2

Blacklock, B. J., and Jaworski, J. G. (2002). Studies into factors contributing to substrate specificity of membrane-bound 3-ketoacyl-CoA synthases. Eur. J. Biochem. 269, 4789-4798. doi: 10.1046/j.1432-1033.2002.03176.x

Bonaventure, G., Salas, J. J., Pollard, M. R., and Ohlrogge, J. B. (2003). Disruption of the FATB gene in Arabidopsis demonstrates an essential role of saturated fatty acids in plant growth. Plant Cell 15, 1020-1033. doi: 10.1105/tpc.008946

Brenna, J. T., and Diau, G. Y. (2007). The influence of dietary docosahexaenoic acid and arachidonic acid on central nervous system polyunsaturated fatty acid composition. Prostaglandins Leukot. Essent. Fatty Acids 77, 247-250. doi: 10.1016/j.plefa.2007.10.016

Cahoon, E. B. (2000). Production of fatty acid components of meadowfoam oil in somatic soybean embryos. Plant Physiol. 124, 243. doi: 10.1104/pp.124.1.243

Cahoon, E. B. (2014). "Development of Camelina as oilseed platform for advanced metabolic engineering and synthetic biology," in Proceedings of the Annual Meeting and Exhibition 2014, St. Louis, MO.

Cahoon, E. B., Shockey, J. M., Dietrich, C. R., Gidda, S. K., and Dyer, G. M. (2007). Engineering oilseeds for sustainable production of industrial and nutritional feedstocks: solving bottlenecks in fatty acid flux. Curr. Opin. Plant Biol. 10, 236-244. doi: 10.1016/j.pbi.2007.04.005
Chinese Academy of Agricultural Sciences, China, and Central Public-interest Scientific Institution Basal Research Fund, Major Research Project of CAAS Science.

\section{ACKNOWLEDGMENTS}

We thank LetPub (www.letpub.com) for its linguistic assistance and scientific consultation during the preparation of this manuscript.

Carlsson, A. S., Zhu, L.-H., Andersson, M., and Hofvander, P. (2014). Platform crops amenable to genetic engineering - a requirement for successful production of bio-industrial oils through genetic engineering. Biocatal. Agric. Biotechnol. 3, 58-64. doi: 10.1016/j.bcab.2013.12.007

Chen, Y., Kelly, E. E., Masluk, R. P., Nelson, C. L., Cantu, D. C., and Reilly, P. J. (2011). Structural classification and properties of ketoacyl synthases. Protein Sci. 20, 1659-1667. doi: 10.1002/pro.712

Chivandi, E., Davidson, B. C., and Erlwanger, K. H. (2008). A comparison of the lipid and fatty acid profiles from the kernels of the fruit (nuts) of Ximenia caffra and Ricinodendron rautanenii from Zimbabwe. Ind. Crops Prod. 27, 29-32. doi: 10.1016/j.indcrop.2007.06.002

Coupland, K. (1996). Nervonic acid compositions. U.S. Patent No 5,994,404. Washington, DC: U.S. Patent and Trademark Office.

Coupland, K., and Langley, N. (1991). Use of nervonic acid and long chain fatty acids for the treatment of demyelinating disorders. U.S. Patent No 519448. Washington, DC: U.S. Patent and Trademark Office.

Coupland, K., and Raoul, Y. (2001). Nervonic acid derivatives, their preparation and use. U.S. Patent No 6,664,406. Washington, DC: U.S. Patent and Trademark Office.

Das, S., Roscoe, T. J., Delseny, M., Srivastava, P. S., and Lakshmikumaran, M. (2002). Cloning and molecular characterization of the Fatty Acid elongase 1 (FAE 1) gene from high and low erucic acid lines of Brassica campestris and Brassica oleracea. Plant Sci. 162, 245-250. doi: 10.1016/S0168-9452(01)00556-8

Dodos, G. S., Karonis, D., Zannikos, F., and Lois, E. (2015). Renewable fuels and lubricants from Lunaria annua L. Ind. Crops Prod. 75, 43-50. doi: 10.1016/j. indcrop.2015.05.046

El-Din, A. A. E., and Hendawy, S. F. (2010). Effect of dry yeast and compost tea on growth and oil content of Borago Officinalis Plant. Res. J. Agric. Biol. Sci. 6, 424-430.

Fan, Y., Meng, H. M., Hu, G. R., and Li, F. L. (2018a). Biosynthesis of nervonic acid and perspectives for its production by microalgae and other microorganisms. Appl. Microbiol. Biotechnol. 102, 3027-3035. doi: 10.1007/s00253-018-8859-y

Fan, Y., Yuan, C., Jin, Y., Hu, G. R., and Li, F. L. (2018b). Characterization of 3-ketoacyl-coA synthase in a nervonic acid producing oleaginous microalgae Mychonastes afer. Algal Res. 31, 225-231. doi: 10.1016/j.algal.2018.02.017

Farquharson, J., Jamieson, E. C., Logan, R. W., Patrick, W. J. A., Howatson, A. G., and Cockburn, F. (1996). Docosahexaenoic and nervonic acids in term and preterm infant cerebral white matter. Prenatal Neonatal Med. 1, 234-240.

Fillet, S., Ronchel, C., Callejo, C., Fajardo, M. J., Moralejo, H., and Adrio, J. L. (2017). Engineering Rhodosporidium toruloides for the production of very longchain monounsaturated fatty acid-rich oils. Appl. Microbiol. Biotechnol. 101, 7271-7280. doi: 10.1007/s00253-017-8461-8

Fofana, B., Duguid, S., and Cloutier, S. (2004). Cloning of fatty acid biosynthetic genes $\beta$-ketoacyl CoA synthase, fatty acid elongase, stearoyl-ACP desaturase, and fatty acid desaturase and analysis of expression in the early developmental stages of flax (Linum usitatissimum L.) seeds. Plant Ence 166, 1487-1496. doi: 10.1016/j.plantsci.2004.01.025

Ghanevati, M., and Jaworski, J. G. (2001). Active-site residues of a plant membranebound fatty acid elongase $\beta$-ketoacyl-CoA synthase, FAE1 KCS. Biochim. Biophys. Acta 1530, 77-85. doi: 10.1016/S1388-1981(00)00168-2

Giddings, G., Allison, G., Brooks, D., and Carter, A. (2000). Transgenic plants as factories for biopharmaceuticals. Nat. Biotechnol. 18, 1151-1155. doi: 10.1038/ 81132 
Gugel, R. K., and Falk, K. C. (2006). Agronomic and seed quality evaluation of Camelina sativa in western Canada. Can. J. Plant Sci. 86, 1047-1058. doi: 10.4141/P04-081

Guo, Y., Mietkiewska, E., Francis, T., Katavic, V., Brost, J. M., Giblin, M., et al. (2009). Increase in nervonic acid content in transformed yeast and transgenic plants by introduction of a Lunaria annua L. 3-ketoacyl-CoA synthase (KCS) gene. Plant Mol. Biol. 69, 565-575. doi: 10.1007/s11103-008-9439-9

Han, J., Lühs, W., Sonntag, K., Zähringer, U., and Frentzen, M. (2001). Functional characterization of $\beta$-ketoacyl-CoA synthase genes from Brassica napus L. Plant Mol. Biol. 46, 229-239. doi: 10.1023/A:1010665121980

Hashemian, S. M. R., Jamaati, H. R., and Velayati, A. A. (2010). Borage, a forgotten Iranian heritage now used in ARDS Treatment. Res. J. Agric. Biol. Sci. 6, 424-430.

Haslam, T. M., and Kunst, L. (2013). Extending the story of very-long-chain fatty acid elongation. Plant Sci. 210, 93-107. doi: 10.1016/j.plantsci.2013.05.008

Huai, D., Zhang, Y., Zhang, C., Cahoon, E. B., Zhou, Y., and Thierry, C. (2015). Combinatorial effects of fatty acid elongase enzymes on nervonic acid production in Camelina sativa. PLoS One 10:e131755. doi: 10.1371/journal. pone. 0131755

Iskandarov, U., Kim, H. J., and Cahoon, E. B. (2014). "Camelina: an emerging oilseed platform for advanced biofuels and bio-based materials," in Plants and BioEnergy. Advances in Plant Biology, Vol. 4, eds M. McCann, M. Buckeridge, and N. Carpita (New York, NY: Springer). doi: 10.1007/1978-1001-4614-93291007_1008

Jadhav, A., Katavic, V., Marillia, E. F., Giblin, E. M., and Taylor, D. C. (2005). Increased levels of erucic acid in Brassica carinata by co-suppression and antisense repression of the endogenous FAD2 gene. Metab. Eng. 7, 215-220. doi: 10.1016/j.ymben.2005.02.003

Jako, C., Kumar, A., Wei, Y., Zou, J.-T., Barton, D. L., Giblin, E. M., et al. (2001). Seed-specific over-expression of an Arabidopsis thaliana cDNA encoding a diacylglycerol acyltransferase enhances seed oil content and seed weight. Plant Physiol. 126, 861-874. doi: 10.1104/pp.126.2.861

James, D. W., Lim, J. E., Keller, J., Plooy, I., Ralston, E., and Dooner, H. K. (1995). Directed tagging of the Arabidopsis FATTY ACID ELONGATION1 (FAE1) gene with the maize transposon activator. Plant Cell 7, 309-319. doi: 10.1105/ tpc.7.3.309

Jart, A. (1978). The fatty acid composition of various cruciferous seeds. J. Am. Oil Chem. Soc. 55, 873-875. doi: 10.1007/BF02671410

Joubès, J., Raffaele, S., Bourdenx, B., Garcia, C., Laroche-Traineau, J., Moreau, P., et al. (2008). The VLCFA elongase gene family in Arabidopsis thaliana: phylogenetic analysis, 3D modelling and expression profiling. Plant Mol. Biol. 67, 547-566. doi: 10.1007/s11103-008-9339-z

Kanrar, S., Venkateswari, J., Dureja, P., Kirti, P. B., and Chopra, V. L. (2006). Modification of erucic acid content in Indian mustard (Brassica juncea) by up-regulation and down-regulation of the Brassica juncea FAT TY ACID ELONGATION1 (BjFAE1) gene. Plant Cell Rep. 25, 148-155. doi: 10.1007/ s00299-005-0068-3

Kasai, N., Mizushina, Y., Sugawara, F., and Sakaguchi, K. (2002). Threedimensional structural model analysis of the binding site of an inhibitor, nervonic acid, of both DNA polymerase beta and HIV-1 reverse transcriptase. J. Biochem. 132, 819-828. doi: 10.1093/oxfordjournals.jbchem.a003292

Katavic, V., Friesen, W., Barton, D. L., Gossen, K. K., Giblin, E. M., Luciw, T., et al. (2001). Improving Erucic Acid content in rapeseed through biotechnology: What Can the Arabidopsis FAE1 and the Yeast SLC1-1 Genes Contribute? ${ }^{1,2}$ Crop Sci. 41, 739-747. doi: 10.2135/cropsci2001.413739x

Kaup, M. T., and Thompson, F. J. E. (2002). A role for diacylglycerol acyltransferase during leaf senescence. Plant Physiol. 129, 1616-1626. doi: 10.1104/pp.003087

Kennedy, E. P. (1961). Biosynthesis of complex lipids. Fed. Proc. 20, 934-940.

Kennedy, E. P., and Weiss, S. B. (1956). The function of cytidine coenzymes in the biosynthesis of phospholipides. J. Biol. Chem. 222, 193-214. doi: 10.1016/ S0021-9258(19)50785-2

Keppley, L. J. W., Walker, S. J., Gademsey, A. N., Smith, J. P., Keller, S. R., Kester, M., et al. (2020). Nervonic acid limits weight gain in a mouse model of diet-induced obesity. FASEB J. 34, 15314-15326. doi: 10.1096/fj.202000525R

Kriese, U., Schumann, E., Weber, W. E., Beyer, M., Brühl, L., and Matthus, B. (2004). Oil content, tocopherol composition and fatty acid patterns of the seeds of 51 Cannabis sativa L. genotypes. Euphytica 137, 339-351. doi: 10.1023/B: EUPH.0000040473.23941.76
Kunst, L., Taylor, D., and Underhill, E. W. (1992). Fatty acid elongation in developing seeds of Arabidopsis thaliana. Plant Physiol. Biochem. 30, 425-434.

Lacey, D. J., and Hills, M. J. (1996). Heterogeneity of the endoplasmic reticulum with respect to lipid synthesis in developing seeds of Brassica napus L. Planta 199, 545-551. doi: 10.1007/BF00195185

Lassner, M. W., and Metz, L. J. G. (1996). A jojoba beta-Ketoacyl-CoA synthase cDNA complements the canola fatty acid elongation mutation in transgenic plants. Plant Cell 8, 281-292. doi: 10.1105/tpc.8.2.281

Lee, R. B. (1973). Mongongo: the ethnography of a major wild food resource. Ecol. Food Nutr. 2, 307-321. doi: 10.1080/03670244.1973.9990351

Lei, Z., Fu, Z., Wen, X., Mu, X., Yin, X., and Zhang, A. (2013). A chemical method of synthesis of nerovous acid. China patent application.

Leonard, C. (1994). Sources and commercial applications of high erucic vegetable oils. Lipid Technol. 4, 79-83.

Lewkowicz, N., Pitek, P., Namieciñska, M., Domowicz, M., and Lewkowicz, P. (2019). Naturally occurring nervonic acid ester improves myelin synthesis by human oligodendrocytes. Cells 8:786. doi: 10.3390/cells8080786

Li, Q., Chen, J., Yu, X., and Gao, J.-M. (2019). A mini review of nervonic acid: source, production, and biological functions. Food Chem. 301:125286. doi: 10.1016/j.foodchem.2019.125286

Li, X., Loo, E. N. V., Gruber, J., Fan, J., Guan, R., Frentzen, M., et al. (2012). Development of ultra-high erucic acid oil in the industrial oil crop Crambe abyssinica. Plant Biotechnol. J. 10, 862-870. doi: 10.1111/j.1467-7652.2012. 00709.x

Li, Z., Ma, S., Song, H., Yang, Z., Zhao, C., David, T., et al. (2020). A 3-ketoacylCoA synthase 11 (KCS11) homolog from Malania oleifera synthesizes nervonic acid in plants rich in 11Z-eicosenoic acid. Tree Physiol. 41, 331-342. doi: 10.1093/treephys/tpaa125

Liang, Q., Li, H., Li, S., Yuan, F., Sun, J., Duan, Q., et al. (2019). The genome assembly and annotation of yellowhorn (Xanthoceras sorbifolium Bunge). GigaScience. 8, 1-15. doi: 10.1093/gigascience/giz071

Litchfield, C. (1970). Tropaeolum speciosum seed fat: a rich source ofcis-15tetracosenoic andcis-17-hexacosenoic acids. Lipids 5, 144-146. doi: 10.1007/ BF02531110

Liu, J., Wang, T., Jiang, Y., Liu, Z., Tian, P., Wang, F., et al. (2020). Harnessing $\beta$-estradiol inducible expression system to overproduce nervonic acid in Saccharomyces cerevisiae. Process Biochem. 92, 37-42. doi: 10.1016/j.procbio. 2020.02.032

Lu, C., and Kang, J. (2008). Generation of transgenic plants of a potential oilseed crop Camelina sativa by Agrobacterium-mediated transformation. Plant Cell Rep. 27, 273-278. doi: 10.1007/s00299-007-0454-0

Lu, C., Napier, J. A., Clemente, T. E., and Cahoon, E. B. (2011). New frontiers in oilseed biotechnology: meeting the global demand for vegetable oils for food, feed, biofuel, and industrial applications. Curr. Opin. Biotechnol. 252-259. doi: 10.1016/j.copbio.2010.11.006

Ma, B., Liang, S., Zhao, D., Xu, A., and Zhang, K. (2004). Study on plants containing nervonic acid. Acta Botan Borealiocciden Sin. 24, 2362-2365.

Ma, Q., Sun, T., Li, S., Wen, J., Zhu, L., Yin, T., et al. (2020). The Acer truncatum genome provides insights into the nervonic acid biosynthesis. Plant J. 104, 662-678. doi: 10.1111/tpj.14954

Ma, Q., Wang, Y., Zhu, L., Bi, C., and Li, Q. (2019). Characterization of the complete chloroplast genome of Acer truncatum Bunge (Sapindales: Aceraceae): a new woody oil tree species producing nervonic acid. Biomed. Res. Int. 2019:7417239. doi: 10.1155/2019/7417239

Martínez, M., and Mougan, I. (1998). Fatty acid composition of human brain phospholipids during normal development. J. Neurochem. 71, 2528-2533. doi: 10.1046/j.1471-4159.1998.71062528.x

Mastebroek, H. D., and Marvin, H. J. P. (2000). Breeding prospects of Lunaria annua L. Ind. Crops Prod. 11, 139-143. doi: 10.1016/S0926-6690(99)00056-4

Meier zu Beerentrup, H., and Röbbelen, G. (1987). Screening for European productions of oilseed with unusual fatty acids. Angew. Bot. 61, 287-303.

Merrill, A. H., Schmelz, E.-M., Wang, E., Dillehay, D. L., Rice, L. G., Meredith, F., et al. (1997). Importance of sphingolipids and inhibitors of sphingolipid metabolism as components of animal diets. J. Nutr. 127(5 Suppl.), 830S-833S. doi: $10.1093 /$ jn/127.5.830S

Mietkiewska, E., Brost, J. M., Giblin, E. M., Barton, D. L., and Taylor, D. C. (2007a). A Teesdalia nudicaulis FAE1 complements the fael mutation in transgenic 
Arabidopsis thaliana plants and shows a preference for elongating oleic acid to eicosenoic acid. Plant Sci. 173, 198-205. doi: 10.1016/j.plantsci.2007.05.001

Mietkiewska, E., Brost, J. M., Giblin, E. M., Barton, D. L., and Taylor, D. C. (2007b). Cloning and functional characterization of the fatty acid elongase 1 (FAE1) gene from high erucic Crambe abyssinica cv. Prophet. Plant Biotechnol. J. 5, 636-645. doi: 10.1111/j.1467-7652.2007.00268.x

Mietkiewska, E., Giblin, E. M., Wang, S., Barton, D. L., Dirpaul, J., Brost, J. M., et al. (2004). Seed-specific heterologous expression of a nasturtium FAE gene in Arabidopsis results in a dramatic increase in the proportion of erucic acid. Plant Physiol. 136, 2665. doi: 10.1104/pp.104.046839

Mietkiewska, E., Hoffman, T. L., Brost, J. M., Giblin, E. M., Barton, D. L., Francis, T., et al. (2008). Hairpin-RNA mediated silencing of endogenous FAD2 gene combined with heterologous expression of Crambe abyssinica FAE gene causes an increase in the level of erucic acid in transgenic Brassica carinata seeds. Mol. Breed. 22, 619-627. doi: 10.1007/s11032-008-9204-4

Millar, A. A., and Kunst, L. (2010). Very-long-chain fatty acid biosynthesis is controlled through the expression and specificity of the condensing enzyme. Plant J. 12, 121-131. doi: 10.1046/j.1365-313X.1997.12010121.x

Moon, H., Smith, M. A., and Kunst, L. (2001). A condensing enzyme from the seeds of Lesquerella fendleri that specifically elongates hydroxy fatty acids. Plant Physiol. 127, 1635-1643. doi: 10.1104/pp.010544

Nguyen, H. T., Park, H., Koster, K. L., Cahoon, R. E., Nguyen, H. T. M., Shanklin, J., et al. (2015). Redirection of metabolic flux for high levels of omega-7 monounsaturated fatty acid accumulation in camelina seeds. Plant Biotechnol. J. 13, 38-50. doi: 10.1111/pbi.12233

Nguyen, H. T., Silva, J. E., Podicheti, R., Macrander, J., Yang, W., Nazarenus, T. J., et al. (2013). Camelina seed transcriptome: a tool for meal and oil improvement and translational research. Plant Biotechnol. J. 11, 759-769. doi: 10.1111/pbi. 12068

Ntoumani, E., Strandvik, B., and Sabel, K. G. (2013). Nervonic acid is much lower in donor milk than in milk from mothers delivering premature infants-Of neglected importance? Prostaglandins Leukot. Essent. Fatty Acids 89, 241-244. doi: 10.1016/j.plefa.2013.06.005

Paul, S., Gable, K., Beaudoin, F., Cahoon, E., and Jaworski, J. (2006). Members of the Arabidopsis FAE1-like 3-Ketoacyl-CoA Synthase gene family substitute for the Elop Proteins of Saccharomyces cerevisiae. J. Biol. Chem. 281, 9018-9029. doi: 10.1074/jbc.M507723200

Pilgeram, A. L., Sands, D. C., Boss, D., Dale, N., and Johnson, D. L. (2007). "Camelina sativa, A Montana Omega3 and fuel crop," in Issues in New Crops and New Uses, eds J. Janick and A. Whipkey (Alexandria, VA: ASHS Press), 129-131.

Poulos, A. (1995). Very long chain fatty acids in higher animals-A review. Lipids 30, 1-14. doi: 10.1007/BF02537036

Puyaubert, J., Dieryck, W., Costaglioli, P., Chevalier, S., Breton, A., and Lessire, R. (2005a). Temporal gene expression of 3-ketoacyl-CoA reductase is different in high and in low erucic acid Brassica napus cultivars during seed development. Biochim. Biophys. Acta 1687, 152-163. doi: 10.1016/j.bbalip.2004. 11.014

Puyaubert, J., Garcia, C., Chevalier, S., and Lessire, R. (2005b). Acyl-CoA elongase, a key enzyme in the development of higherucic acid rapeseed? Eur. J. Lipid Sci. Technol. 107, 263-267. doi: 10.1002/ejlt.200590024

Qiao, Q., Xue, W., and Feng, Z. (2018). Variability of seed oil content, fatty acid composition, and nervonic acid content in Acer truncatum, native to 14 regions of China. Grasas Aceites 69:e274. doi: 10.3989/gya.0465181

Raffaele, S., Vailleau, F., Léger, A., Miersch, O., Huard, C., Blée, E., et al. (2008). A MYB transcription factor regulates very-long-chain fatty acid biosynthesis for activation of the hypersensitive cell death response in Arabidopsis. Plant Cell 20, 752-767. doi: 10.1105/tpc.107.054858

Rong, S., Wu, Z., Cheng, Z., Zhang, S., Liu, H., and Huang, Q. (2020). Genomewide identification, evolutionary patterns, and expression analysis of bZIP gene family in olive (Olea europaea L.). Genes 11:510. doi: 10.3390/genes110 50510

Salas, J. J., Martínez-Force, E., and Garcés, R. (2005). Very long chain fatty acid synthesis in sunflower kernels. J. Agric. Food Chem. 53, 2710-2716. doi: 10. 1021/jf047939e

Salas, J. J., and Ohlrogge, J. B. (2002). Characterization of substrate specificity of plant FatA and FatB acyl-ACP thioesterases. Arch. Biochem. Biophys. 403, 25-34. doi: 10.1016/S0003-9861(02)00017-6
Sargent, J. R., Coupland, K., and Wilson, R. (1994). Nervonic acid and demyelinating disease. Med. Hypotheses 42, 237-242. doi: 10.1016/03069877(94)90122-8

Scarth, R., and Tang, J. (2006). Modification of Brassica oil using conventional and transgenic approaches. Crop Sci. 46, 1225-1236. doi: 10.2135/cropsci2005.080245

Sinclair, A. J., and Crawford, M. A. (1972). The incorporation of linolenic acid and docosahexaenoic acid into liver and brain lipids of developing rats. FEBS Lett. 26, 127-129. doi: 10.1016/0014-5793(72)80557-X

Soest, J. V. (1994). "Alternative crop developments in the Netherlands," in Proceedings of a Work- Shop 1994 Alternative Oilseed and Fibre Crops for Cool and Wet Regions of Europe, Wageningen, 14-20.

Tang, J., Scarth, R., and Fristensky, B. (2003). Effects of genomic position and copy number of Acyl-ACP thioesterase transgenes on the level of the target fatty acids in Brassica napus L. Mol. Breed. 12, 71-81. doi: 10.1023/A:102549500 0264

Tang, T. F., Liu, X. M., Ling, M., Lai, F., Zhang, L., Zhou, Y. H., et al. (2013). Constituents of the essential oil and fatty acid from Malania oleifera. Ind. Crops Prod. 43, 1-5. doi: 10.1016/j.indcrop.2012.07.003

Taylor, D. C., Francis, T., Guo, Y., Brost, J. M., Katavic, V., Mietkiewska, E., et al. (2009). Molecular cloning and characterization of a KCS gene from Cardamine graeca and its heterologous expression in Brassica oilseeds to engineer high nervonic acid oils for potential medical and industrial use. Plant Biotechnol. J. 7, 925-938. doi: 10.1111/j.1467-7652.2009.00454.x

Taylor, D. C., Guo, Y., Katavic, V., Mietkiewska, E., Francis, T., and Bettger, W. (2008). "New seed oils for improved human and animal health and as industrial feedstocks: genetic manipulation of the Brassicaceae to produce oils enriched in nervonic acid," in Modification of Seed Composition to Promote Health and Nutrition, ed. H. E. Krishnan (Madison, WI: American Society of Agronomy), 98-101.

Taylor, D. C., Katavic, V., Zou, J. T., Mackenzie, S. L., Keller, W. A., An, J., et al. (2001). Field-testing of transgenic rapeseed cv. Hero transformed with a yeast sn-2 acyltransferase results in increased oil content, erucic acid content and seed yield. Mol. Breed. 8, 317-322. doi: 10.1023/A:1015234401080

Taylor, D. C., Smith, M. A., Fobert, P., Mietkiewaska, E., and Weselake, R. J. (2011). Metabolic engineering of higher plants to produce bio-industrial oils. Compr. Biotechnol. 4, 67-85. doi: 10.1016/B978-0-08-088504-9.00256-7

Tjellström, H., Strawsine, M., Silva, J., Cahoon, E. B., and Ohlrogge, J. B. (2013). Disruption of plastid acylacyl carrier protein synthetases increases medium chain fatty acid accumulation in seeds of transgenic Arabidopsis. FEBS Lett. 587, 936-942. doi: 10.1016/j.febslet.2013.02.021

Tsujimoto, M., and Kimura, K. (1926). New fatty acids in shark - liver oil. J. Soc. Chem. 46, 385-388.

Umemoto, H., Sawada, K., Kurata, A., Hamaguchi, S., Tsukahara, S., Ishiguro, T., et al. (2014). Fermentative production of nervonic acid by Mortierella capitata RD000969. J. Oleo Sci. 63, 671-679. doi: 10.5650/jos.ess14029

Van Meer, G., Voelker, D. R., and Feigenson, G. W. (2008). Membrane lipids: Where they are and how they behave. Nat. Rev. Mol. Cell Biol. 9, 112-124. doi: $10.1038 / \mathrm{nrm} 2330$

Venter, F., and Venter, J. A. (1996). Making the Most of Indigenous Trees. Pretoria: BRIZA Publications.

Vozella, V., Basit, A., Misto, A., and Piomelli, D. (2017). Age-dependent changes in nervonic acid-containing sphingolipids in mouse hippocampus. Biochim. Biophys. Acta 1862, 1502-1511. doi: 10.1016/j.bbalip.2017.08.008

Wang, R., Liu, P., Fan, J., and Li, L. (2018). Comparative transcriptome analysis two genotypes of Acer truncatum Bunge seeds reveals candidate genes that influences seed VLCFAs accumulation. Sci. Rep. 8:15504. doi: 10.1038/s41598018-33999-3

Wang, X. Y., Fan, J. S., Wang, S. Y., and Sun, R. C. (2006). A new resource of nervonic acid from purpleblow maple (Acer truncatum) seed oil. For. Prod. J. $56,147-150$.

Weiser, M. J., Christopher, M. B., and Mohajeri, M. H. (2016). Docosahexaenoic Acid and Cognition throughout the Lifespan. Nutrients 8:99. doi: 10.3390/ nu8020099

Wu, G. Z., and Xue, H. W. (2010). Arabidopsis $\beta$-ketoacyl-[acyl carrier protein] synthase $\mathrm{i}$ is crucial for fatty acid synthesis and plays a role in chloroplast division and embryo development. Plant Cell 22, 3726-3744. doi: 10.1105/tpc. 110.075564 
Xu, C. Q., Liu, H., Zhou, S. S., Zhang, D. X., Zhao, W., Wang, S., et al. (2019). Genome sequence of Malania oleifera, a tree with great value for nervonic acid production. Gigascience 2:giy164. doi: 10.1093/gigascience/giy164

Xu, F., Fan, Y., Miao, F., Hu, G. R., Sun, J., Yang, G., et al. (2018). Naphthylacetic acid and Tea polyphenol application promote biomass and lipid production of nervonic acid-producing microalgae. Front. Plant Sci. 9:506. doi: 10.3389/fpls. 2018.00506

Yamamoto, A., Kagaya, Y., Toyoshima, R., Kagaya, M., and Hattori, T. (2009). Arabidopsis NF-YB subunits LEC1 and LEC1-LIKE activate transcription by interacting with seed-specific ABRE-binding factors. Plant J. 58, 843-856. doi: 10.1111/j.1365-313X.2009.03817.x

Yang, T., Yu, Q., Xu, W., Li, D., and Chen, F. (2018). Transcriptome analysis reveals crucial genes involved in the biosynthesis of nervonic acid in woody Malania oleifera oilseeds. BMC Plant Biol. 18:247. doi: 10.1186/s12870-0181463-6

Yu, J., Yuan, T., Zhang, X., Jin, Q., Wei, W., and Wang, X. (2019). Quantification of nervonic acid in human milk in the first 30 days of lactation: influence of lactation stages and comparison with infant formulae. Nutrients 11:1892. doi: 10.3390/nu11081892

Yu, T., Zhou, Y., Wenning, L., Liu, Q., Krivoruchko, A., Siewers, V., et al. (2017). Metabolic engineering of Saccharomyces cerevisiae for production of very long chain fatty acid-derived chemicals. Nat. Commun. 8:15587. doi: 10.1038/ ncomms 15587

Yuan, C., Liu, J., Fan, Y., Ren, X., Hu, G., and Li, F. (2011). Mychonastes afer HSO-3-1 as a potential new source of biodiesel. Biotechnol. Biofuels 4:47. doi: 10.1186/1754-6834-4-47

Zakim, D., and Herman, R. H. (1969). Regulation of fatty acid synthesis. Annu. Rev. Plant Physiol. Plant Mol. Biol. 22, 109-136.

Zhang, X., Hao, Y., Wang, X., and Chen, Z. (2017). Adsorption of iron(iii), cobalt(ii), and nickel(ii) on activated carbon derived from Xanthoceras Sorbifolia bunge hull: mechanisms, kinetics and influencing parameters. Water Sci. Technol. 75, 1849-1861. doi: 10.2166/wst.2017.067
Zheljazkov, V. D., Vick, B., Ebelhar, M. W., Buehring, N., and Astatkie, T. (2012) Nitrogen applications modify seed and oil yields and fatty acid composition of winter mustard. Ind. Crops Prod. 36, 28-32. doi: 10.1016/j.indcrop.2011. 08.002

Zheng, H., Rowland, O., and Kunst, L. (2005). Disruptions of the Arabidopsis Enoyl-CoA reductase gene reveal an essential role for very-long-chain fatty acid synthesis in cell expansion during plant morphogenesis. Plant Cell 17, 1467-1481. doi: 10.1105/tpc.104.030155

Zheng, W., Kollmeyer, J., Symolon, H., Momin, A., Munter, E., Wang, E., et al. (2006). Ceramides and other bioactive sphingolipid backbones in health and disease: lipidomic analysis, metabolism and roles in membrane structure, dynamics, signaling and autophagy. Biochim. Biophys. Acta Biomembr. 1758, 1864-1884. doi: 10.1016/j.bbamem.2006.08.009

Zou, J., Katavic, V., Giblin, E. M., Barton, D. L., Mackenzie, S. L., Keller, W. A., et al. (1997). Modification of seed oil content and acyl composition in the brassicaceae by expression of a yeast sn-2 acyltransferase gene. Plant Cell 9 , 909-923. doi: 10.1105/tpc.9.6.909

Conflict of Interest: XZh was employed by Life Science and Technology Center, China National Seed Group Co. Ltd., Wuhan, China.

The remaining authors declare that the research was conducted in the absence of any commercial or financial relationships that could be construed as a potential conflict of interest.

Copyright (c) 2021 Liu, Wang, Xiong, Zeng, Zhang and Wu. This is an open-access article distributed under the terms of the Creative Commons Attribution License (CC BY). The use, distribution or reproduction in other forums is permitted, provided the original author(s) and the copyright owner(s) are credited and that the original publication in this journal is cited, in accordance with accepted academic practice. No use, distribution or reproduction is permitted which does not comply with these terms. 